\title{
Diet of Engraulis encrasicolus in the northern Adriatic Sea (Mediterranean): ontogenetic changes and feeding selectivity
}

\author{
D. Borme ${ }^{1}$, V. Tirelli ${ }^{1, *}$, S. B. Brandt ${ }^{2}$, S. Fonda Umani ${ }^{3}$, E. Arneri ${ }^{4}$ \\ ${ }^{1}$ OGS, Istituto Nazionale di Oceanografia e di Geofisica Sperimentale, Dipartimento di Oceanografia Biologica, \\ Via A. Piccard 54, 34014 S. Croce, Trieste, Italy \\ ${ }^{2}$ Oregon Sea Grant Program, Oregon State University, 322 Kerr Administration Building, Corvallis, Oregon 97331-2131, USA \\ ${ }^{3}$ Department of Life Sciences, University of Trieste, via Valerio 28/A, 34143 Trieste, Italy \\ ${ }^{4}$ CNR-ISMAR, Sezione Pesca Marittima Largo Fiera della Pesca, 60125 Ancona, Italy
}

\begin{abstract}
Ontogenetic variation in the diet of Engraulis encrasicolus (L.) was examined in the northern Adriatic Sea, off the River Po delta, by stomach contents analysis. Anchovy (10 to $130 \mathrm{~mm}$ total length) were collected during a 1 wk cruise in October 2002. Feeding activity was mainly diurnal in all the length classes: stomach fullness, calculated for each $10 \mathrm{~mm}$ size class, was always higher during the day than at night, with maximal values measured for the 40 to 49 and 50 to $59 \mathrm{~mm}$ size classes. All analysed life stages of $E$. encrasicolus had a strictly zooplanktivorous diet based on a few species of copepods. The principal prey of E. encrasicolus were small-sized copepods, measuring about 0.2 to 0.3 or 0.5 to $0.6 \mathrm{~mm}$ in prosoma length. The copepods Euterpina acutifrons and Oncaea spp. dominated anchovy diet during the day, both in terms of frequency, number and biomass, in all anchovy size classes. During the night, bivalve larvae were also important dietary items, with Oncaea spp. and E. acutifrons making up $>69 \%$ of total prey number for all anchovy size classes. Within the considered size range, the dimensions of particles does not seem to be a limiting factor in food selection, and no relationship was found between anchovy length and the maximal dimension of ingested prey. Ivlev's electivity index confirmed that European anchovy was able to select specific food items and preferred small copepods such as E. acutifrons and Oncaea spp., and bivalve and decapod larvae.
\end{abstract}

KEY WORDS: Anchovy $\cdot$ Late larvae $\cdot$ Stomach contents $\cdot$ Prey selection $\cdot$ Zooplankton

\section{INTRODUCTION}

European anchovy Engraulis encrasicolus (Linnaeus, 1758) is a coastal pelagic species of the Engraulidae family distributed across the eastern Atlantic and the Mediterranean, Black and Azov seas (Whitehead et al. 1988). E. encrasicolus is one of the major components of Mediterranean fisheries, where it is heavily exploited by purse seine vessels and pelagic trawlers. The Adriatic Sea, occupying about $5 \%$ of the Mediterranean Sea, produced about 13000 tonnes of anchovy, equal to $19 \%$ of the entire Mediterranean production of this species in 1991 (Stamatopoulos 1993).

The importance of small pelagic fish, and anchovy in particular, in the Adriatic Sea food web was recently pointed out by Coll et al. (2007). They highlighted the importance of medium-low trophic levels, such as sardine and anchovy, in the functioning of the ecosystem due to their role in capturing energy and making it available to the higher trophic levels. Moreover, anchovy was found (Coll et al. 2007) to be one of the keystone species within the Adriatic ecosystem when applying the index proposed by Libralato et al. (2006) based on the total mixed trophic impacts of the food web.

Fish abundance and production is critically dependent on both trophic linkages and environmental conditions (e.g. Christensen \& Pauly 2004). Engraulis encrasicolus is characterized by a short life-span, and interannual fluctuations in its abundance could be important and more evident in comparison with other species. 
Several studies on Engraulis species have demonstrated that anchovy can feed by filtering or particulate feeding (O'Connell 1972, James 1987, James \& Findlay 1989, van der Lingen 1994, Bulgakova 1996, van der Lingen et al. 2006, 2009). The ability to switch between these feeding modes makes anchovy highly opportunistic and flexible foragers, which are able to maximize their energy intake through employing the feeding mode most appropriate to a particular food environment. Given this ability, the diet of anchovy, which is generally comprised of mesozooplanktonic prey, may also include smaller particles such as phytoplanktonic cells (King \& Macleod 1976, Mikhman \& Tomanovich 1977, Bulgakova 1996). The feeding behaviour of anchovies and the resulting variability or breadth in their food intake make field and laboratory studies regarding selectivity the only means of predicting their diet in any particular ecosystem.

Robert et al. (2008) recently pointed out the importance of carrying out field studies coupling fish gut contents analysis and prey availability assessment. In fact, the knowledge of prey availability is essential in order to understand the relative importance of food categories and to assess prey selectivity. Moreover, Robert et al. (2008) stressed the importance of obtaining high taxonomical resolution in the identification of prey in selectivity studies, this being mandatory to identify the key prey species to consider, rather than the entire prey field, for assessing any relationship between fish and their trophic environment.

Current knowledge concerning the trophic ecology of Engraulis encrasicolus is primarily limited to studies carried out on adults (Black Sea, Bulgakova 1996; Azov Sea, Budnichenko et al. 1999; Catalan Sea, Tudela \& Palomera 1995, 1997, Palomera et al. 2007; Bay of Biscay, Plounevez \& Champalbert 1999; Gulf of Lions, Plounevez \& Champalbert 2000), although assessments of the diets of larval stages have been conducted in the Western Mediterranean (Tudela et al. 2002) and the Adriatic Sea $(<10 \mathrm{~mm}$; Regner 1971, Conway et al. 1998, Coombs et al. 2003). However, knowledge concerning the trophic ecology of juveniles from silvering to pre-spawning stage is still lacking.

The present study focuses on the diet of late larvae and juvenile anchovy to complete missing information on feeding ecology of Engraulis encrasicolus and provide the basis for future investigation of the trophic ecology of this species in the Adriatic Sea. For this purpose, a multidisciplinary investigation was conducted, coupling fish stomach contents analysis and contemporary plankton net sampling. The simultaneous capture of late larvae, juveniles and adults during a $1 \mathrm{wk}$ cruise carried out near the River Po delta provided the opportunity to examine anchovy diet with the aims of (1) determining the major components of the diet,
(2) examining anchovy feeding patterns in relation to ontogenesis, (3) identifying feeding periodicity, and (4) studying food selectivity.

\section{MATERIALS AND METHODS}

Study area. The study area was located in the northwestern Adriatic Sea, near the Po River delta (off Pesaro), across a transect nearly perpendicular to the coast (Fig. 1). The northern Adriatic spans from the continental northern border to the $-100 \mathrm{~m}$ contour line: it features an extremely shallow mean depth of ca. $30 \mathrm{~m}$ and a weak depth gradient along the major axis together with a strong annual thermal variation $\left(8\right.$ to $25^{\circ} \mathrm{C}$ at the sea surface; Poulain et al. 2001). Freshwater inputs in this region represent nearly $20 \%$ of the entire Mediterranean's inputs (Mariotti et al. 2002). Shallow depths and gentle sea-bottom slope greatly affect the hydrology of the basin, reducing the time of water mass exchange, which may occur over a few months. Stormy winds from the NE and SE allow water mixing, thus enhancing the recirculation of the nutrients. All these characteristics create a highly productive system (Buljan 1964, Franco 1973, Fonda Umani et al. 1992, Fonda Umani 1996) which makes this basin one of the richest in the Mediterranean, producing about $85 \%$ of the total Italian landings of small pelagic fish (Cingolani et al. 2003). Moreover, anchovy spawning in the Adriatic Sea, although widespread, is generally quantitatively more important in the northern areas and, in particular, in the study area around the Po river delta (Piccinetti 2001).

Fish sampling. The survey was carried out aboard the RV 'G. Dalla Porta' from 20 to 23 October 2002. The vessel was equipped with an echo sounder (BIOSONIC DT 600) which was used to detect fish aggregations during sampling. Fish were sampled by a semipelagic trawl net equipped with a fine-meshed cod-end (mesh length $5 \mathrm{~mm}$, ISO 1107), towed at an approximate speed of 3.0 knots for $30 \mathrm{~min}$. The net was also equipped with a temperature/depth recorder (VEMCO MINILOG TD). Overall, 11 tows (Table 1) were carried out along the transect, but only 4 (Tows 1, 3, 7 and 9) landed an adequate number of specimens of a wide size range. Only the samples from these tows were considered in the present study. Anchovy were captured both during the day and night (Table 1) in a near-shore position (Fig. 1). Adult and juvenile fish were randomly sampled from every haul, immediately frozen at $-20^{\circ} \mathrm{C}$ to stop digestive processes and preserved at the same temperature until laboratory analysis. Early developmental stages were immediately fixed in $10 \%$ buffered formaldehyde. The term 'late larva' refers to individuals with completed yolk sac resorption $(\simeq 10-39 \mathrm{~mm})$; 'juveniles' are individuals in 


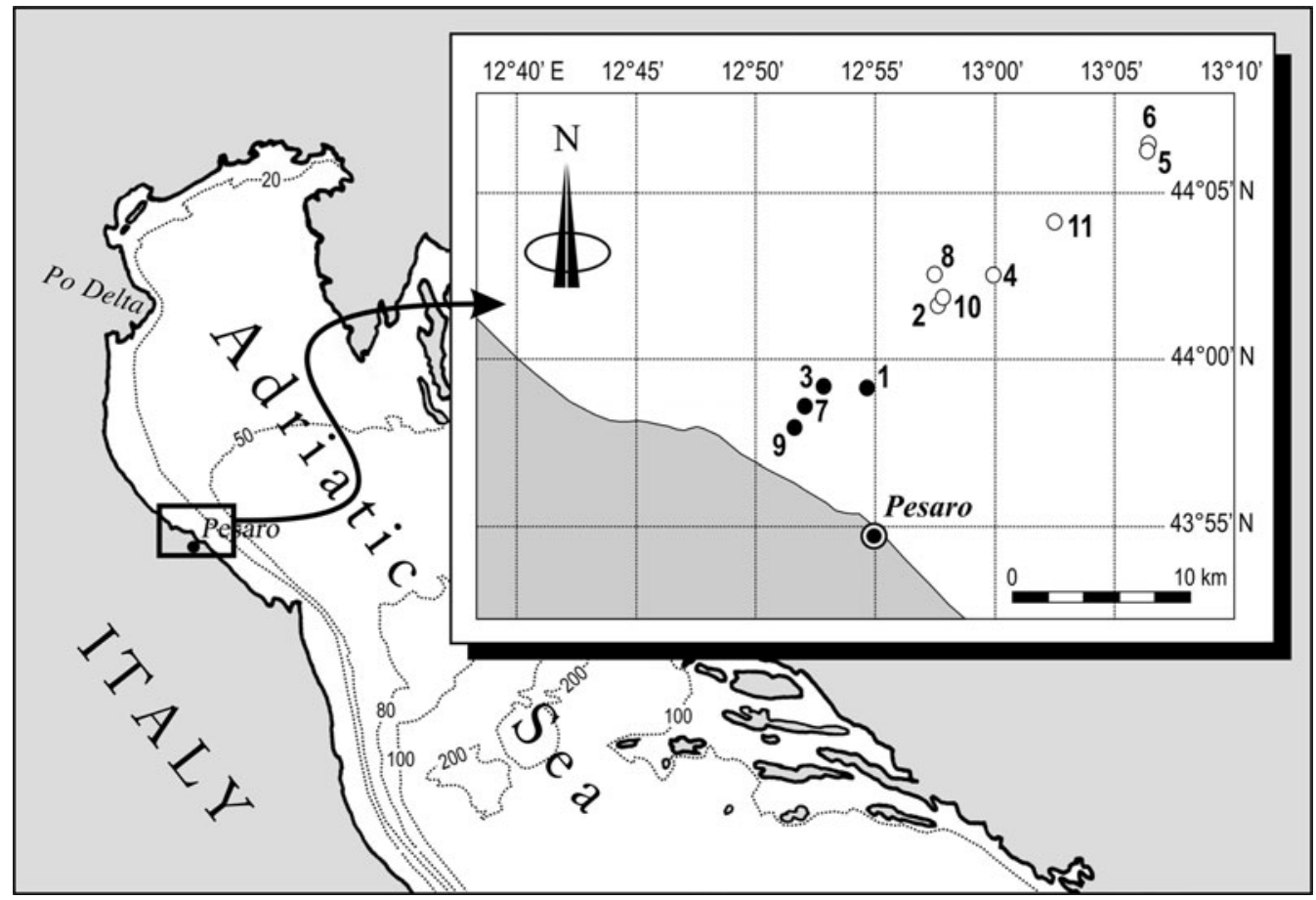

Fig. 1. Location of the sampling stations where anchovy Engraulis encrasicolus were captured, off the coast of NE Italy in October 2002. (-) tows where anchovy diet was studied; (O) tows where anchovy diet was not studied. Bathymetry is shown (m)

which silvering had already started $(\simeq 40-89 \mathrm{~mm})$ and individuals $>90 \mathrm{~mm}$ total length are considered 'adults' (Sinovčić 1999).

In the laboratory, fish total length (TL), to the nearest $0.1 \mathrm{~mm}$, and fish wet weight, to the nearest $0.0001 \mathrm{~g}$, were measured for each individual. Since larvae undergo shrinkage due to fixation in formaldehyde, their length was converted into real length at sea by applying the correction factor of 1.03 previously obtained for Engraulis mordax (Theilacker 1980).

Table 1. Sampling information for anchovy trawls and zooplankton tows. Times indicate the start of hauls and refer to GMT+1. Sampling depth indicates where both anchovy and zooplankton were collected. ${ }^{*}$ : hauls considered for diet analysis

\begin{tabular}{|lcccccc|}
\hline Tow & Date & $\begin{array}{c}\text { Latitude } \\
\left({ }^{\circ} \mathrm{N}\right)\end{array}$ & $\begin{array}{c}\text { Longitude } \\
\left({ }^{\circ} \mathrm{E}\right)\end{array}$ & $\begin{array}{c}\text { Depth } \\
(\mathrm{m})\end{array}$ & Time & $\begin{array}{c}\text { Sampling } \\
\text { depth }(\mathrm{m})\end{array}$ \\
\hline $1^{*}$ & $20 / 10 / 02$ & $43^{\circ} 59.16^{\prime}$ & $12^{\circ} 54.64^{\prime}$ & 13 & $00: 43$ & 10 \\
2 & & $44^{\circ} 01.68^{\prime}$ & $12^{\circ} 57.72^{\prime}$ & 23 & $04: 25$ & 10 \\
$3^{*}$ & & $43^{\circ} 59.20^{\prime}$ & $12^{\circ} 52.85^{\prime}$ & 13 & $10: 45$ & 10 \\
4 & & $44^{\circ} 02.54^{\prime}$ & $12^{\circ} 59.91^{\prime}$ & 23 & $17: 05$ & 22 \\
5 & $21 / 10 / 02$ & $44^{\circ} 06.28^{\prime}$ & $13^{\circ} 06.35^{\prime}$ & 55 & $00: 16$ & 28 \\
6 & & $44^{\circ} 06.48^{\prime}$ & $13^{\circ} 06.42^{\prime}$ & 55 & $08: 13$ & 53 \\
$7^{*}$ & & $43^{\circ} 58.59^{\prime}$ & $12^{\circ} 52.06^{\prime}$ & 13 & $20: 35$ & 10 \\
8 & & $44^{\circ} 02.55^{\prime}$ & $12^{\circ} 57.46^{\prime}$ & 23 & $23: 04$ & 18 \\
$9^{*}$ & $23 / 10 / 02$ & $43^{\circ} 57.95^{\prime}$ & $12^{\circ} 51.61^{\prime}$ & 13 & $13: 10$ & 10 \\
10 & & $44^{\circ} 01.87^{\prime}$ & $12^{\circ} 57.83^{\prime}$ & 23 & $15: 04$ & 20 \\
11 & & $44^{\circ} 04.15^{\prime}$ & $13^{\circ} 02.49^{\prime}$ & 45 & $16: 51$ & 40 \\
\hline
\end{tabular}

Mesozooplankton sampling and analyses. Zooplankton sampling took place immediately after fish trawling. Net hauls were taken using a WP-2 standard net $\left(0.25 \mathrm{~m}^{2}\right.$ opening, $200 \mu \mathrm{m}$ mesh size) equipped with an opening-closing system, a depth sensor and a flowmeter. The plankton net was towed horizontally for 2 to $3 \mathrm{~min}$ at the depth of the previous fish sampling. On board, samples were then stored in a buffered $4 \%$ formaldehyde-seawater solution. Taxonomical analyses were performed on subsamples of at least 1000 individuals. Individuals of each identified taxon were counted and their relative abundances in different hauls were calculated as individuals per cubic meter. Organisms were identified to the lowest taxonomical level possible.

The species Oithona nana, O. similis, $O$. plumifera and $O$. setigera were grouped as Oithona spp. Similarly, the genera Paracalanus, Ctenocalanus, Clausocalanus and Parvocalanus were classified as the 'Clauso-Paracalanidae' group.

Stomach content analyses. For dietary analyses, 663 fish were dissected and the digestive tract of at least 10 anchovies for each $10 \mathrm{~mm}$ size class 
per single tow were removed and preserved individually in $4 \%$ buffered formaldehyde. The stomach content was defined as the material contained in the pyloric and cardiac stomachs, while the content of the intestine was discarded to reduce bias caused by different rates of digestion and gut passage times (Berg 1979, Hyslop 1980). Regurgitation during sampling was not observed since no food was found in the oesophagus. In late larvae, where the stomachs were not yet developed, the entire digestive tract was examined, from oesophagus to anus.

Dissection took place under a stereo-microscope and the entire stomach content of each fish was washed out on a Petri dish and examined individually (at 70 to $90 \times$ magnification). Prey items were identified, if possible, to species level, counted and measured. Diatoms, dinoflagellates and other microplankton were also identified. When items were damaged, only heads were counted. The prosoma length of all copepods or the maximum dimension of other zooplankton was measured using an ocular micrometer, with a precision of $14 \mu \mathrm{m}$. The original size of incomplete prey was estimated from whole individuals captured in zooplankton samples.

The dry weight of the total stomach content was mathematically reconstructed on the basis of literature references or direct measurements (Table 2). The contribution in terms of weight of dinoflagellates, tintinnids and diatoms was not considered because of their low abundance and their comparatively insignificant weight.

To compare the feeding intensity of individual fish of different sizes, the fullness index $(F)$ was calculated as:

$$
F=[\mathrm{SCW} /(\mathrm{BW}-\mathrm{SCW})] \times 1000
$$

where SCW is the stomach content dry weight (g) and BW the fish body dry weight $(\mathrm{g})$. Gonad weight was not considered in this fullness index because the majority of fish were sexually immature individuals or, if mature, they were at the end of their reproductive cycle and gonads were not evident. Wet weight of fish analysed for diet were transformed to dry weight using the relationship $\left(\mathrm{DW}=0.2607 \times \mathrm{WW} ; \mathrm{r}^{2}\right.$ $=0.97$ ) obtained by drying 234 individuals $(\mathrm{TL}=40.5$ to $128.7 \mathrm{~mm})$. For the day/night ratio of fullness index, the fullness index was calculated for each $10 \mathrm{~mm}$ fish size class, separately for day and night samples.

Mean values of the numerical abundance and dry weight of prey found in stomachs were calculated for each $10 \mathrm{~mm}$ anchovy size class. Since the data were not normally distributed (Kolmogorov-Smirnov test with Lilliefors' correction), the non-parametric 1-way ANOVA (Kruskal-Wallis test) was used to evaluate sig- nificant differences between fish samples in terms of prey number per fish and stomach content dry weight per fish.

A cluster analysis based on similarity in feeding habits was applied on an anchovy size class-prey consumed matrix, using the Primer v.5 package (Clarke \& Warwick 2001), to evaluate possible clustering of samples between anchovy size classes and time of catch. The matrix was made up of 22 anchovy groups (12 size classes from nocturnal and 10 size classes from diurnal tows) and all taxa of prey consumed. The mean value of prey abundance in each size class was used. The Bray-Curtis coefficient of similarity (Bray \& Curtis 1957) and the group-average method of linkage was applied to $\log _{10}(x+1)$-transformed data. All specimens of each group, or cluster, obtained from the cluster analysis were used for analysis of the diet, except for empty stomachs which were not used to calculate the frequency of occurrence.

The dietary analysis was carried out using both numerical and gravimetric methods, calculating number and weight of each prey item as well as the frequency of occurrence (Hyslop 1980, Cortés 1997). The index of relative importance (IRI, Pinkas et al. 1971), which incorporates the relative contribution of a food item to total stomach content by number $(\% \mathrm{~N})$ and by weight $(\% \mathrm{DW})$, as well as the percent frequency of occurrence $(\% \mathrm{O})$, was calculated as:

$$
\text { IRI }=(\% \mathrm{~N}+\% \mathrm{DW}) \times \% \mathrm{O}
$$

To verify if any size-related selection of food occurs in anchovy, prey identified in stomach contents and mesozooplankton obtained by net-plankton sampling were grouped into $0.1 \mathrm{~mm}$ size classes. Size-frequency histograms were constructed for prey eaten by each group of fish identified by cluster analysis (anchovy sized 30 to 39 and 40 to $104 \mathrm{~mm}$ ) and were subsequently compared with those of the plankton from the environment.

Finally, to assess the relationship between stomach contents and the abundance of potential prey in the sea, Ivlev's selection index ( $E$; Ivlev 1955) was calculated for each prey category separately for day and night samples:

$$
E=\left(r_{i}-p_{i}\right)\left(r_{i}+p_{i}\right)-1
$$

where $r_{i}$ is the relative abundance of prey category $i$ $(\% \mathrm{~N})$ in the stomachs of Engraulis encrasicolus and $p_{i}$ is the abundance of that prey in the horizontal netplankton samples. $E$ ranges from -1 to +1 ; negative and positive values indicate avoidance or positive selection for a prey category, respectively. A zero value indicates neutral selectivity. 
Table 2. Dry weight (DW) of Engraulis encrasicolus prey and morphometric relationships used to calculate DW ( $\mu$ g). For certain prey, DW was obtained by conversion of their carbon content (CW/DW) or directly measured. n: number of specimens weighed;

Ø: diameter; CW: carbon weight $(\mu \mathrm{g})$; PL: prosome length $(\mu \mathrm{m})$; L: total length $(\mu \mathrm{m})$. Superscripts ${ }^{\mathrm{a}}$ and $^{\mathrm{b}}$ refer to sources

\begin{tabular}{|c|c|c|c|c|c|}
\hline Prey item & DW & $\begin{array}{l}\text { Regression } \\
\text { (length-DW) }\end{array}$ & $\begin{array}{c}\text { C/DW } \\
(\%)\end{array}$ & $\mathrm{n}$ & Source \\
\hline Gastropoda larvae & & $\mathrm{DW}=0.6^{\mathrm{a}}$ & $31.25^{\mathrm{b}}$ & & $\begin{array}{l}\text { Sautour \& Castel }(1995)^{\mathrm{a}}, \\
\text { James }(1987)^{\mathrm{b}}\end{array}$ \\
\hline Bivalvia veliger & 3.758 & Mean & & 740 & La Mesa et al. (2008) \\
\hline Polychaeta larvae & 5.670 & Mean & & 114 & La Mesa et al. (2008) \\
\hline $\begin{array}{l}\text { Evadne spp. } \\
\text { (ref. Cladocerans) }\end{array}$ & & $\mathrm{DW}=3.946 \mathrm{~L}^{2.436}$ & & & James (1987) \\
\hline Penilia avirostris & 1.2 & Mean & & & Fonda Umani et al. (1979) \\
\hline Podon poliphemoides & 1.6 & Mean & & & Fonda Umani et al. (1979) \\
\hline $\begin{array}{l}\text { Evadne spp. eggs } \\
\text { (ref. copepods and } \\
\text { euphausian eggs) }\end{array}$ & & $\operatorname{lnDW}=0.0143 \varnothing-3.381$ & & & van der Lingen (2002) \\
\hline Ostracod juveniles & 6.035 & Mean & & 94 & Present study \\
\hline Acartia clausi & & $\log \mathrm{DW}=2.71 \log \mathrm{PL}-7.28$ & & & Cataletto \& Fonda Umani (1994) \\
\hline Calanus helgolandicus & & $\log \mathrm{DW}=2.691 \log \mathrm{PL}-6.883$ & & & Hay et al. (1991) \\
\hline $\begin{array}{l}\text { Calocalanus pavo } \\
\text { Nannocalanus minor } \\
\text { Paracalanus spp. } \\
\text { (ref. P. parvus) }\end{array}$ & & $\log \mathrm{DW}=2.738 \log \mathrm{PL}-6.934$ & & & Hay et al. (1991) \\
\hline $\begin{array}{l}\text { Centropages kroyeri } \\
\text { C. typicus }\end{array}$ & & $\log \mathrm{DW}=2.451 \log \mathrm{PL}-6.103$ & & & Hay et al. (1991) \\
\hline Temora longicornis & & $\log \mathrm{DW}=2.815 \log \mathrm{PL}-7.181$ & & & Hay et al. (1991) \\
\hline Temora stylifera & & $\log \mathrm{DW}=(2.71 \log \mathrm{PL}-3.685) / 1000$ & & & Razouls (1981) \\
\hline $\begin{array}{l}\text { Clauso-Paracalanidae in } \\
\text { October (ref. P. parvus) }\end{array}$ & & $\log \mathrm{DW}=2.738 \log \mathrm{PL}-6.934$ & & & Hay et al. (1991) \\
\hline $\begin{array}{l}\text { Clauso-Paracalanidae in } \\
\text { May (ref. Acartia clausi) }\end{array}$ & & $\log \mathrm{DW}=2.71 \log \mathrm{PL}-7.28$ & & & Cataletto \& Fonda Umani (1994) \\
\hline Oithona similis & & $C W=\left(9.4676 \times 10^{-7}\right) \mathrm{PL}^{2.16 \mathrm{a}}$ & $40^{\mathrm{b}}$ & & $\begin{array}{l}\text { Sabatini \& Kiørboe }(1994)^{\mathrm{a}} \text {, } \\
\text { Kiørboe \& Sabatini }(1994)^{\mathrm{b}}\end{array}$ \\
\hline $\begin{array}{l}\text { Copilia spp. } \\
\text { Corycaeus speciosus } \\
\text { Corycaeus spp. } \\
\text { Clytemnestra rostrata }\end{array}$ & & $\operatorname{lnDW}=1.96 \ln P L-11.64$ & & & van der Lingen (2002) \\
\hline Oncaea spp. & 1.34 & Mean & & 1000 & Present study \\
\hline Euterpina acutifrons & & $\mathrm{DW}=\left(1.389 \times 10^{-8}\right) \mathrm{PL}^{2.857}$ & & & Ara (2001) \\
\hline $\begin{array}{l}\text { Microsetella rosea } \\
\text { Other harpacticoids } \\
\text { (ref. M. norvegica) }\end{array}$ & & $\mathrm{CW}=\left(2.65 \times 10^{-6}\right) \mathrm{PL}^{1.95}$ & 40 & & Uye et al. (2002) \\
\hline $\begin{array}{l}\text { Copepod nauplii } \\
\text { (ref. Acartia nauplii) }\end{array}$ & & $\log \mathrm{DW}=2.848 \log \mathrm{L}-7.265$ & & & Durbin \& Durbin (1978) \\
\hline $\begin{array}{l}\text { Copepod copepodites } \\
\text { (ref. Acartia copepodites) }\end{array}$ & & $\log \mathrm{DW}=3.095 \log \mathrm{PL}-8.195$ & & & Durbin \& Durbin (1978) \\
\hline $\begin{array}{l}\text { Cirripeda larvae } \\
\text { Decapod nauplii }\end{array}$ & & $\mathrm{CW}=0.67^{\mathrm{a}}$ & $39.97^{b}$ & & $\begin{array}{l}\text { Sautour \& Castel }(1995)^{\mathrm{a}} \text {, } \\
\text { James }(1987)^{\mathrm{b}}\end{array}$ \\
\hline Decapod larvae & 27.798 & Mean & & 61 & La Mesa et al. (2008) \\
\hline $\begin{array}{l}\text { Macruran larvae } \\
\text { (ref. euphausians) }\end{array}$ & & $\mathrm{DW}=1.9(\mathrm{~L} / 1000)^{3.19}$ & & & James (1987) \\
\hline $\begin{array}{l}\text { Isopods } \\
\text { (ref. harpacticoids) }\end{array}$ & & $\operatorname{lnDW}=1.96 \ln L-11.64$ & & & Chisholm \& Roff (1990) \\
\hline Amphipods & 1181 & Mean & & 2 & Present study \\
\hline Invertebrate eggs & & & 40 & & Present study \\
\hline $\begin{array}{l}\text { Sagitta spp. } \\
\text { (ref. Sagitta elegans) }\end{array}$ & 1430 & & & & Omori 1969 \\
\hline Engraulis mordax eggs & 30 & & & & Hunter \& Dorr (1982) \\
\hline $\begin{array}{l}\text { Engraulis encrasicolus } \\
\text { larvae }\end{array}$ & & $\mathrm{DW}=\left(6 \times 10^{-15}\right) \mathrm{L}^{4.13}$ & & $\begin{array}{c}100 \\
\left(\mathrm{r}^{2}=0.9654\right)\end{array}$ & Present study \\
\hline
\end{tabular}




\section{RESULTS}

\section{Diet composition}

The smallest anchovies (TL $<30 \mathrm{~mm}$ ) often had empty stomachs (Table 3 ), thus diet composition was analysed in detail only for fish between 30 and $129 \mathrm{~mm}$ TL. Dietary indices ( $\% \mathrm{~N}, \% \mathrm{O}, \% \mathrm{DW}$ and IRI) were calculated for late larvae (30 to $39 \mathrm{~mm}$ ), juveniles (40 to $89 \mathrm{~mm}$ ) and adults (>90 mm) and separately summarized for night and day sampling (Appendix 1, Table A1). The diet of European anchovy consisted of a wide variety of planktonic organisms (50 prey items recognised) and comprised mainly zooplankton. A total of 120009 (119416 mesoplanktonic and 593 microplanktonic organisms) prey items were identified. Overall, only 587 phytoplankton cells were recovered in 104 fish (minimum and maximum values $=1$ and 46 phytoplankton cells stomach ${ }^{-1}$, respectively). Nevertheless, the bulk of stomach contents was formed by few prey. The copepods Euterpina acutifrons (Harpacticoida) and Oncaea spp. (Poecilostomatoida) dominated anchovy diet during the day, in terms of frequency, number and biomass, in all the fish size classes. At night, bivalve larvae were also important (IRI $=43.34,40.22$ and $24.86 \%$ for late larvae, juveniles and adults, respectively) and, with Oncaea spp. and E. acutifrons, made up $>69 \%$ of total prey number for all anchovy size classes $(\% \mathrm{~N}=76.52,78.2$ and $69.71 \%$ for late larvae, juveniles and adults, respectively).

\section{Diel and ontogenetic variation in feeding}

The simultaneous sampling of a wide range of size classes of anchovy allowed us to examine ontogenetic variation in diet. Overall, 663 specimens of Engraulis encrasicolus, ranging from 10.8 to $128.8 \mathrm{~mm}$ in total length and from 0.0021 to $13.4500 \mathrm{~g}$ wet weight, were analysed for diet.

The number of prey per stomach ranged between 0 and 4073, with greater abundance in fish caught during daytime (maximal abundance of prey at night was 606 prey stom$\mathrm{ach}^{-1}$ ) (Fig. 2). Prey abundance was very low (Table 3) in anchovy $<30 \mathrm{~mm}$ TL and increased consistently in fish 40 to $60 \mathrm{~mm}$ TL (Fig. 2). Stomach fullness, calculated for each $10 \mathrm{~mm}$ size class, (Fig. 3), was always higher during the day than at night, with maximal values measured in the 40 to 49 and 50 to $59 \mathrm{~mm}$ size classes (mean $F=7.5$ ); minimal values were recovered for 10 to 19 and 20 to $29 \mathrm{~mm}$ size classes because larval guts were almost always empty (Table 3 ; 148 empty, 12 with food). In particular, the fullness index day/night ratio was 4.6 in late larvae and ranged from 2.2 to 6.1 in juveniles and 3.6 to 12.0 in adults. The fullness index for the 100 to $109 \mathrm{~mm}$ size class was calculated without considering the ingestion of 3 anchovy late larvae by adult specimens. In fact, cannibalism was observed in only 3 of the 663 anchovy analysed and is probably due to cod-end feeding.

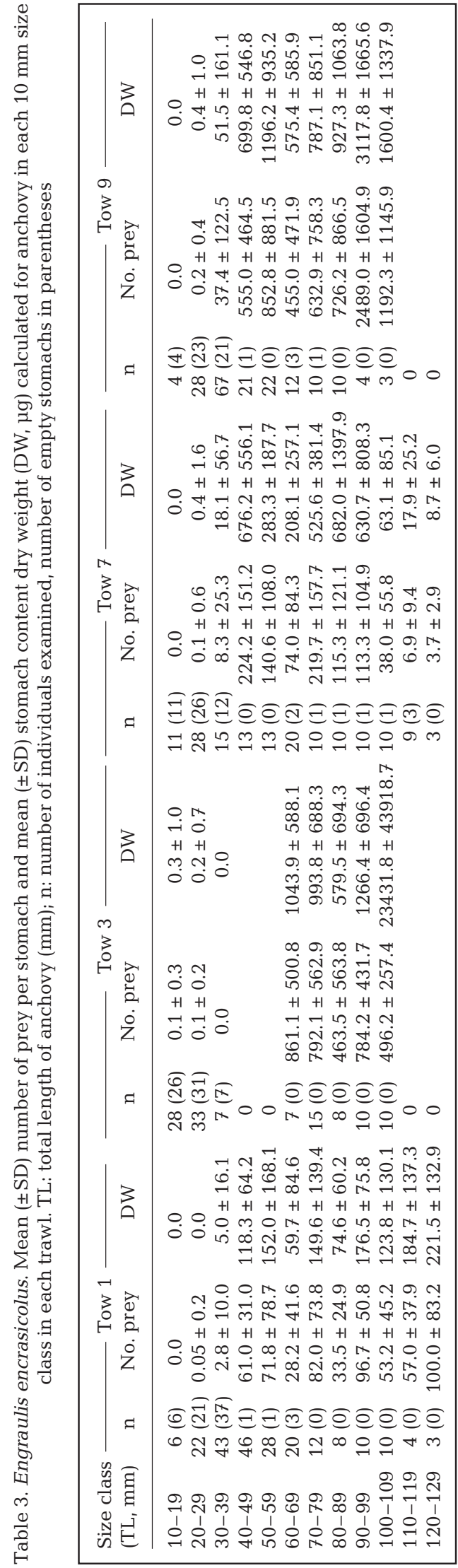


The mean values of the numerical abundance and dry weight of prey found in the stomachs were calculated for each $10 \mathrm{~mm}$ size class. There were no significant differences between samples from the nocturnal Tows 1 and 7 (Kruskal-Wallis test: $\mathrm{p}=0.436$ for prey number stomach $^{-1}, \mathrm{p}=0.402$ for stomach content DW), nor for diurnal Tows 3 and $9(p=0.505$ for prey number stomach $^{-1}, p=0.894$ for stomach content DW). On the contrary, differences were significant between night and day samples $(\mathrm{p}=$ 0.017 for prey number stomach ${ }^{-1}, \mathrm{p}=0.031$ for stomach content DW).

In the following analyses, samples were pooled together (Tows 1 and 7 as nocturnal; Tows 3 and 9 as diurnal).

The clustering of fish groups on the basis of mean prey number per stomach provided the dendrogram shown in Fig. 4. The borderline of cluster definition was arbitrarily set at $57.5 \%$ similarity and this resulted in a division of the dendrogram into 8 fish clusters. Diurnal and nocturnal samples were never present in the same cluster. Groups $\mathrm{n} 1$ and $\mathrm{n} 2$ differed considerably from other clusters and referred to fish sized 10 to $19 \mathrm{~mm}$ and 20 to $29 \mathrm{~mm}$, respectively, with almost empty stomachs at night (n). During the day (d), anchovies of these sizes (clusters $\mathrm{d} 1$ and $\mathrm{d} 2$ ) consumed some prey and were more similar to adjacent clusters. These dimensions characterized late-larval individuals whose digestive tracts were not yet completely formed, as observed during dissection. A more defined stomach was observed in anchovy 30 to $39 \mathrm{~mm}$ TL (clusters $3 \mathrm{n}$ and $3 \mathrm{~d}$ ), and this, coupled with the finding of a larger number of prey, suggesting an increased ingestion capacity. Anchovy between 40 and $120 \mathrm{~mm}$ TL included juveniles and adults and formed 2 clusters only ( $4 \mathrm{n}$ and $4 \mathrm{~d}$ ), clearly separating diurnal and nocturnal samples.

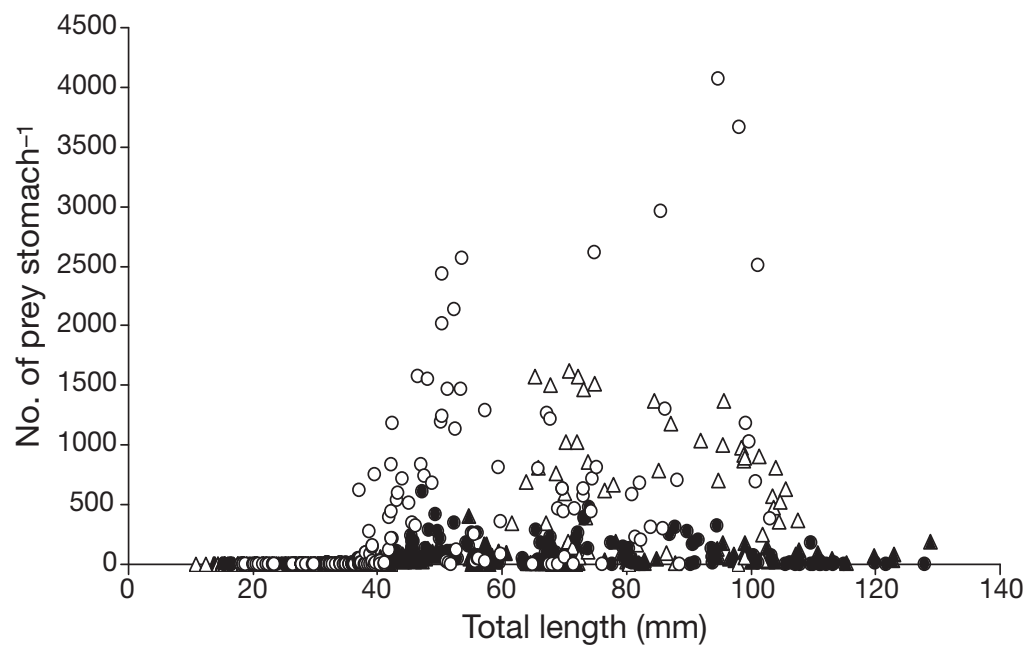

Fig. 2. Engraulis encrasicolus. Number of prey per stomach relative to total length of anchovy in each trawl. Tows $1(\boldsymbol{\Delta})$ and $7(\bullet)$ were nocturnal tows and Tow $3(\Delta)$ and $9(O)$ were diurnal tows

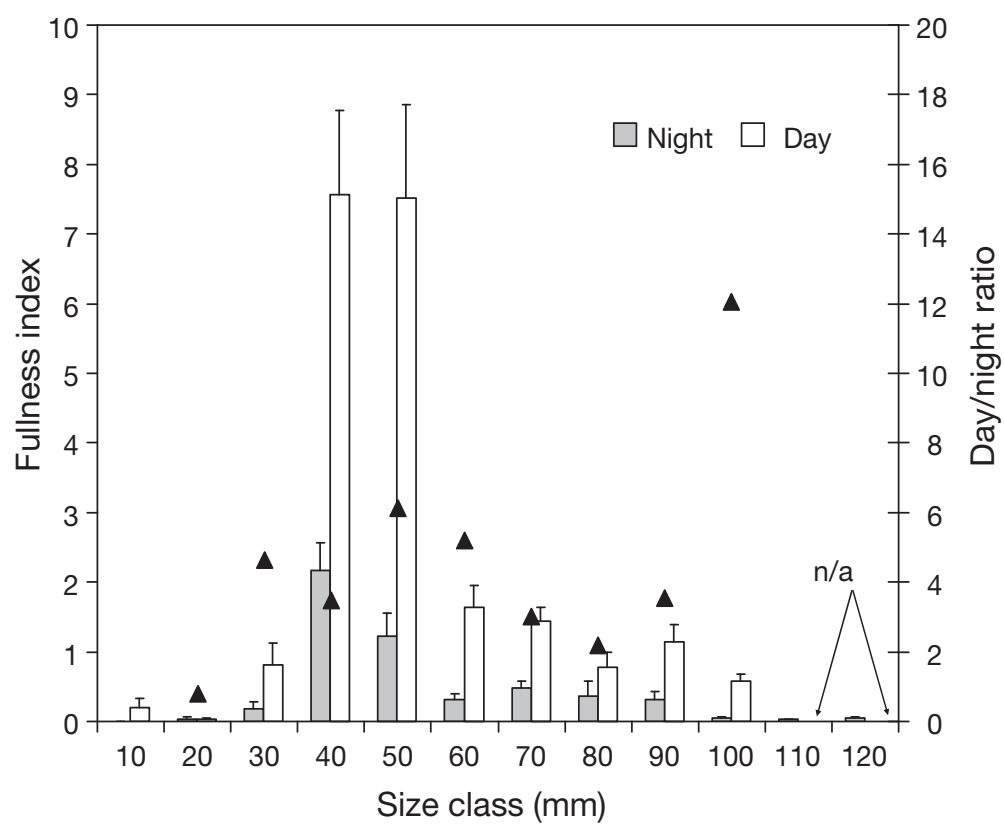

Fig. 3. Engraulis encrasicolus. Fullness index $(F)$ for anchovy. Size classes are in $10 \mathrm{~mm}$ increments. Mean values $( \pm \mathrm{SE})$ at night and day and the day/night ratio $(\boldsymbol{\Lambda})$ are presented. n/a: data not available for day sampling

\section{Feeding selection}

Prey dimensions ranged between $70 \mu \mathrm{m}$ and $38.6 \mathrm{~mm}$. No relationship was found between anchovy TL and maximal prey size, since larvae and juveniles fed on the same plankton size classes as adults (Fig. 5). As a consequence, mouth width did not seem to be a limiting factor for the smallest anchovies when compared to adults.
The size frequency of planktonic organisms in the field and of the prey recovered in the stomachs presented 2 main, non-overlapping, peaks (Fig. 6): the highest size frequencies of mesozooplanktonic organisms at sea were 0.3 to 0.4 and 0.6 to $0.7 \mathrm{~mm}$, while that of prey recovered in the stomachs were 0.2 to 0.3 and 0.5 to $0.6 \mathrm{~mm}$. This pattern was observed during both day and night. The prosoma length of Oncaea spp. (0.21 to $0.28 \mathrm{~mm}$ ) and the total length of Euterpina acu- 
tifrons $(0.49$ to $0.56 \mathrm{~mm})$, the main prey items of anchovy during the considered period, were within the range of the peaks of prey dimensions.

Ivlev's selection index was used to describe the selection of the food items among the planktonic organisms present in the environment (Fig. 7). The species composition of zooplankton (ind. $\mathrm{m}^{-3}$ ) from horizontal plankton-net tows is presented in Appendix 1, Table A2. Copepods represented the main component of the mesozooplankton. Calanoids were characterized by Temora stylifera and other species of the families Clausocalanidae and Paracalanidae. Euterpina acutifrons and the genus Oncaea were the most abundant species of Harpacticoids and Poecilostomatoids, respectively. Cyclopoids were represented by Oithona plumifera and Oithona nana. The most representative cladocerans were Penilia avirostris and Evadne nordmanni. The meroplankton community was dominated by ophioplutei and bivalve veligers.

During night feeding, selection was positive for bivalves, ostracods, Oncaea spp., E. acutifrons and Microsetella rosea in all the size groups of anchovy. As length increased (juvenile and adult anchovy), Corycaeus spp. and decapod larvae were also positively selected, while polychaete larvae were negatively selected. During day feeding, selection was positive for Oncaea spp., E. acutifrons and M. rosea in all size groups. Decapod larvae were positively selected only by late larvae and bivalves only by adults. ClausoParacalanidae copepods were very abundant at sea (Table A2), but they were poorly selected by anchovy of all size groups. Some planktonic organisms, despite being very abundant in the environment, were never found in the stomach contents. This was the case for

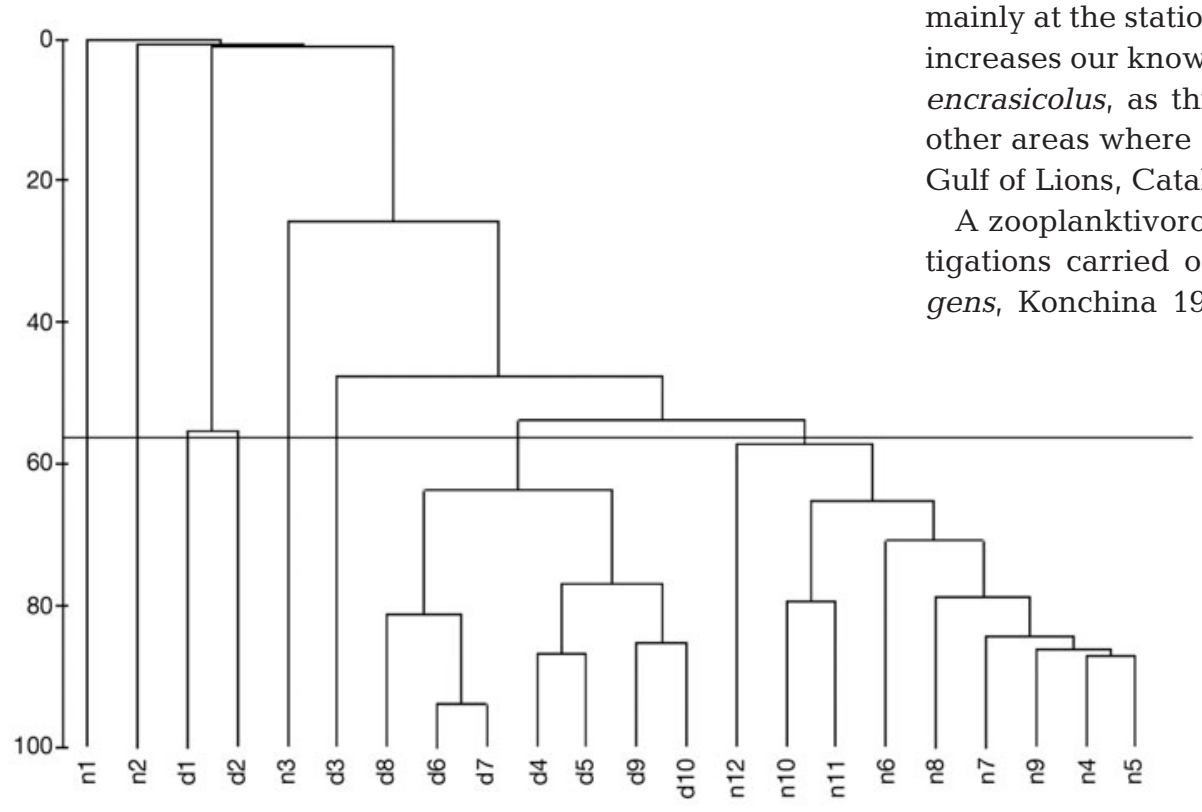

ophiopluteii, siphonophores, appendicularians and doliolids, which numerically constituted altogether 43.73 and $35.11 \%$ of net-plankton at night and day, respectively.

\section{DISCUSSION}

\section{Diet composition}

In the present study we present for the first time a description of the diet of juvenile stage of Engraulis encrasicolus. Our results show that all analysed life stages of E. encrasicolus had a strictly zooplanktivorous diet based on a few species of copepods. The diets of juveniles and adults were dominated by small copepods, both in terms of number and biomass. Among copepods, Euterpina acutifrons and Oncaea spp. appear to be of particular importance. A shift in prey importance was noted during the growth of individuals (from 30 to $39 \mathrm{~mm}$ to $>40 \mathrm{~mm}$ ), with diurnal IRI values of E. acutifrons decreasing from $78.5 \%$ (late larvae) to $48.26 \%$ (juveniles) and $43.92 \%$ (adults) and Oncaea spp. increasing from $14.6 \%$ (late larvae) to $45.45 \%$ (juveniles) and $37.16 \%$ (adults). The genus Oncaea has been previously described as particularly important for anchovy diet (Tudela \& Palomera 1997, Plounevez \& Champalbert 1999, 2000, Sciolis 2000, Tanaka et al. 2006). Of particular interest is the importance of bivalve larvae in the nocturnal anchovy diet, as shown both by IRI and Ivlev's selection index in all anchovy ontogenetic stages (Table A1, Fig. 7). In the Adriatic Sea, the abundance of bivalves is very important, as is evident from the abundance of bivalve larvae presented in the results on zooplankton composition, mainly at the stations where anchovy was caught. This increases our knowledge on the feeding plasticity of $E$. encrasicolus, as this result has not been reported for (e.g. ulf of Lions, Catalan Sea, Bay of Biscay).

zooplanktivorous diet was reported in most investigations carried out on the genus Engraulis (E. ringens, Konchina 1991; E. mordax, Koslow 1981, Chi-

Fig. 4. Engraulis encrasicolus. Dendrogram resulting from the analysis of the anchovy size class-prey consumed matrix. n: night; d: day. Size classes 1 to 12 correspond to $10 \mathrm{~mm}$ intervals, i.e. size class 1 is 10 to $19 \mathrm{~mm}, 2$ is 20 to $29 \mathrm{~mm}$ and so on until 12, which is 120 to $129 \mathrm{~mm}$. Horizontal line is the borderline of cluster definition (arbitrarily set at $57.5 \%$ similarity) 


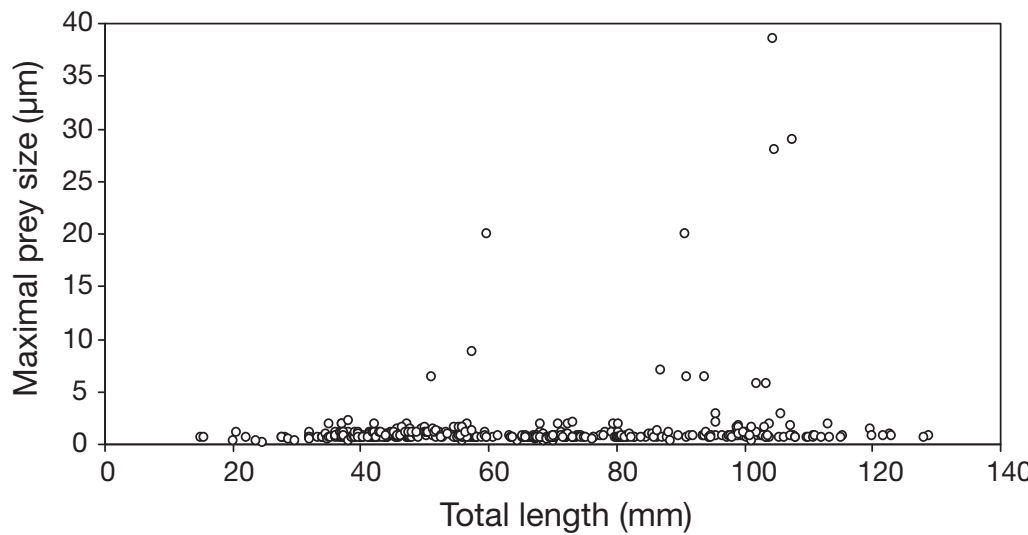

Fig. 5. Engraulis encrasicolus. Maximal prey size $(\mu \mathrm{m})$ versus anchovy total length $(\mathrm{mm})$

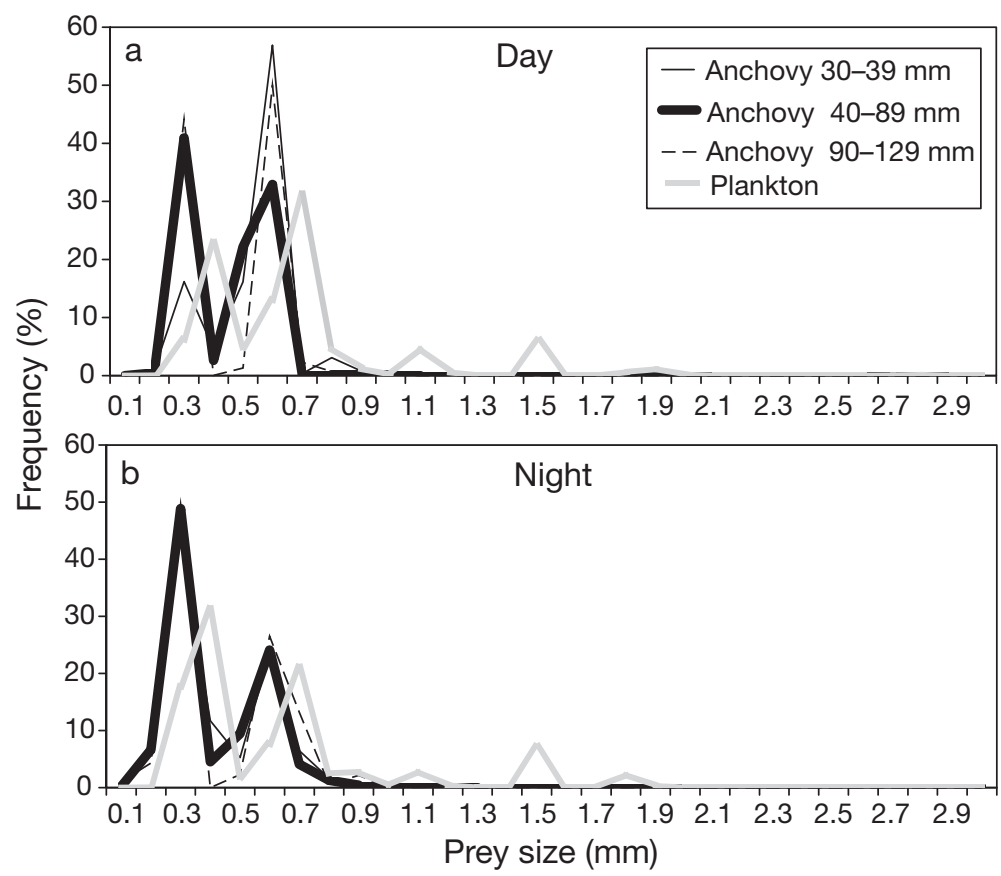
the environment (grey line) and from stomach contents of late larvae (30 to $39 \mathrm{~mm}$, black line), juvenile (40 to $89 \mathrm{~mm}$, thick black line) and adult ( $\geq 90 \mathrm{~mm}$, dotted line) anchovy (a) during the day and (b) at night
Fig. 6. Engraulis encrasicolus. Length frequency of plankton specimens from

was probably due to the development, during growth, of a more efficient filtering system, with a decreasing porosity among branchial spines, allowing the retention of smaller food particles. Some studies on anchovy adults from the Black and Azov seas have shown that diet could include microphytoplankton (Mikhman \& Tomanovich 1977, Bulgakova 1996) and tintinnids (Ferreira \& Ré 1993). In accordance with these authors, Budnichenko et al. (1999) observed that $87 \%$ of E. encrasicolus maeoticus stomach contents comprised microphytoplankton (Coscinodiscus spp.), while mesozooplankton was rare.

Recently, Rossi et al. (2006), using fatty acids as trophic markers, observed that prymnesiophycean fatty acids were transferred to anchovy larvae in the NW Mediterranean. Since these phytoplanktonic cells are mainly represented by nanoflagellates, probably too small to be efficiently eaten by anchovy larvae, the authors suggested that the microalgae are most likely ingested by the fish via naked and nonnaked protozoan prey which have consumed the algae. This means that microzooplankton could be an intermediate trophic step between phytoplankton and anchovy larvae. Fukami et al. (1999), who carried out an experimental study on the identification of naked protozoans in fish larvae, reported the presence of flagellate-like cells $5 \mu \mathrm{m}$ in size and ciliate-like cells 20 to $30 \mu \mathrm{m}$ in size in the gut contents of several species of fish larvae, but they did not observe any protists in the gut contents of Engraulis japonicus. In the present study, predation on naked protozoans by anchovy late larvae ( $\geq 30 \mathrm{~mm}$ ) could not be excluded, although few tintinnids and dinoflagellates were observed. This finding appears to minimise the importance of a direct microzooplankton-anchovy late larvae

appa-Carrara \& Gallardo-Cabello 1993; E. anchoita, Angelescu \& Anganuzzi 1981; E. capensis, James 1987; E. encrasicolus, Bulgakova 1996, Mikhman \& Tomanovich 1977, Tudela \& Palomera 1997, Plounevez \& Champalbert 1999, 2000; E. japonicus, Tanaka et al. 2006). Conversely, James (1987) observed large diatoms (e.g. Rhizosolenia, Pleurosigma and CoscinodisCus) in the gut contents of E. capensis. King \& Macleod (1976) showed that specimens of E. capensis were zooplanktivorous in the larval stages, but they progressively became phytoplanktivorous, eating mostly diatoms. The change in diet occurred at $80 \mathrm{~mm}$ TL and trophic link in the northern Adriatic Sea.

Although our study area is known as one of the most productive in the Adriatic Sea (Degobbis et al. 2000, Totti et al. 2000), phytoplankton (diatoms and dinoflagellates, mainly belonging to the genera Coscinodiscus and Protoperidinium) was observed in less than one-sixth of the analysed gut contents and always in very low concentrations (1 to 46 phytoplankton cells stomach $^{-1}$ ). According to James (1987), small food particles could have been accidentally taken up during particulate feeding. Moreover, other observations, made in the same area in spring and year-round in the 
Night

E

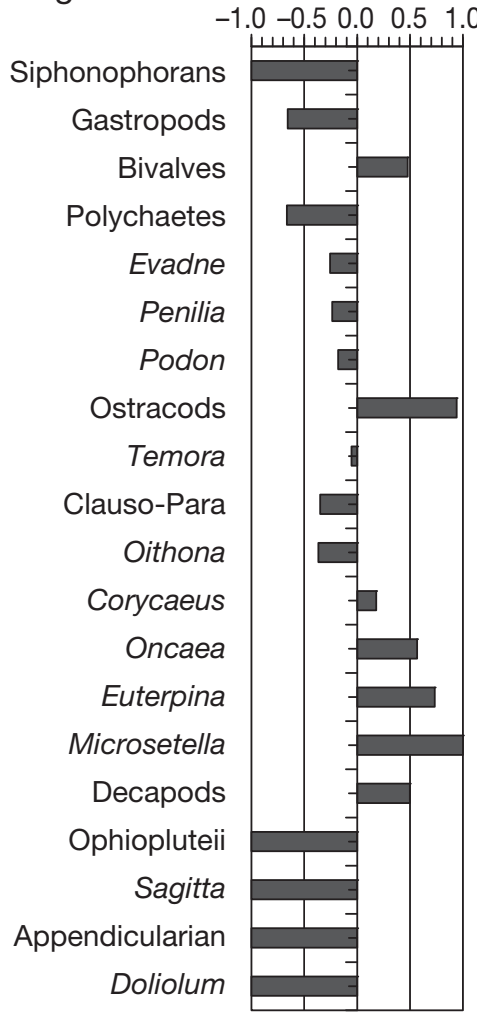

Day

$\begin{array}{lllll}-1.0 & -0.5 & 0.0 & 0.5 & 1.0\end{array}$

Siphonophorans

Gastropods

Bivalves

Polychaetes

Evadne

Penilia

Podon

Ostracods

Temora

Oithona

Corycaeus

Oncaea

Euterpina

Microsetella

Decapods

Ophiopluteii

Sagitta

Appendicularian

Doliolum

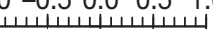

шسшा

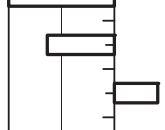

Clauso-Para
E

$\begin{array}{lllll}-1.0 & -0.5 & 0.0 & 0.5 & 1.0\end{array}$

Siphonophorans

Gastropods

Bivalves

Polychaetes

Evadne

Penilia

Podon

Ostracods

Temora

Clauso-Para

Oithona

Corycaeus

Oncaea

Euterpina

Decapods

Ophiopluteii

Sagitta

$\stackrel{\triangleright}{\stackrel{2}{二}}$

Appendicularian

Doliolum

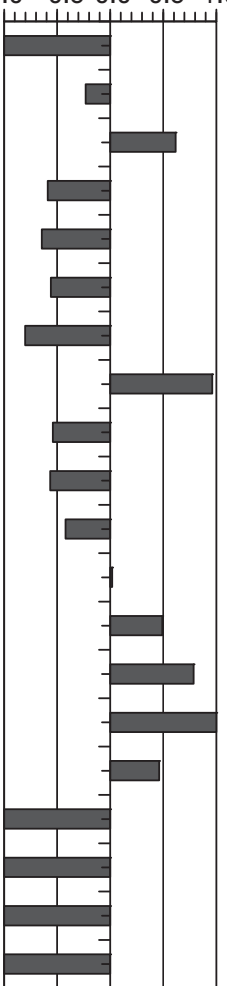

กั่

ญे

Siphonophorans

Gastropods

Bivalves

Polychaetes

Evadne

Penilia

Podon

Ostracods

Temora

Clauso-Para

Oithona

Corycaeus

Oncaea

Euterpina

Microsetella

Decapods

Ophioplutei

Sagitta

Appendicularian

Doliolum
Microsetella
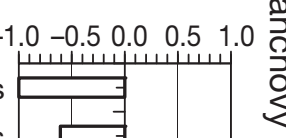

Siphonophorans

Gastropods

Bivalves

Polychaetes

Evadne

Penilia

Podon

Ostracods

Temora

Clauso-Para

Oithona

Corycaeus

Oncaea

Euterpina

Microsetella

Decapods

Ophioplutei

Sagitta

Appendicularian

Doliolum
E

$\begin{array}{lllll}-1.0 & -0.5 & 0.0 & 0.5 & 1.0\end{array}$ سلسنسنسنس

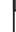

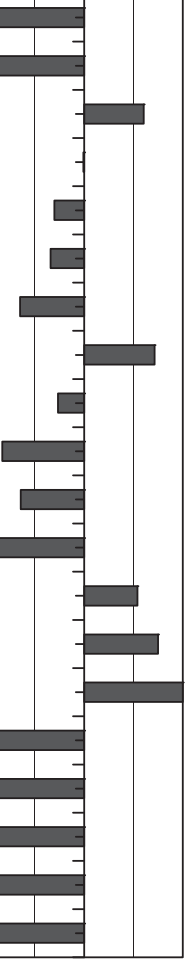

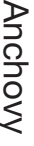
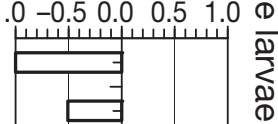

Fig. 7. Engraulis encrasicolus. Ivlev's selection index (E), calculated for anchovy late larvae (30 to $39 \mathrm{~mm})$, juveniles (40 to $89 \mathrm{~mm})$ and adults $(\geq 90 \mathrm{~mm})$ during the day (white bars) and at night (black bars). Clauso-Para: Clauso-Paracalanidae 
Gulf of Trieste (Italy), confirm that phytoplankton is not abundantly present in the diet of European anchovy (D. Borme unpubl. data).

The cladoceran Penilia avirostris has been indicated as an important component of the diet and the ecology of Engraulis encrasicolus in the Adriatic Sea (Štirn 1969, Specchi et al. 1999). Štirn (1969) proposed that this cladoceran was the pivotal link of a short and very efficient trophic chain with the diatom Nitzschia spp. as the primary producer, the phytoplanktivorous P. avirostris as the primary consumer and anchovy as its predator. Specchi et al. (1999) confirmed this hypothesis, verifying the synchronism between the occurrence of the cladoceran and the appearance of anchovy in the Gulf of Trieste (northern Adriatic). In contrast, Ogawa \& Nakahara (1979) found that high concentrations of cladocerans could produce unfavourable effects on the feeding activity of small planktivores. In the present study, P. avirostris was found in stomach contents mainly at night (Table A1), but it never represented an important prey even if it was abundant at sea, especially in the area where anchovy were caught (>3000 individuals $\mathrm{m}^{-3}$; Table A2).

\section{Diel and ontogenetic variation in feeding}

Significant differences in anchovy diet were found between diurnal and nocturnal catches. Feeding activity of Engraulis encrasicolus was mainly diurnal, in accordance with previous reports (Tudela \& Palomera 1995, 1997, Plounevez \& Champalbert 1999, 2000). However, the analysis of gut contents revealed the presence of recently ingested prey even at night, suggesting that some nocturnal feeding activity exists. Dietary indexes, based on stomach contents analyses measured in larvae of various species, show significant diel variability, with activity generally higher during the day and peaks at dusk and dawn (Last 1978, Kane 1984, Blaxter 1986, McLaren \& Avendaño 1995, McLaren et al. 1998).

The results obtained from the cluster analysis confirmed the differences between day and night samples. Moreover, the size classes 10 to 19,20 to 29 and 30 to $39 \mathrm{~mm}$ appeared to be more differentiated than size classes from 40 to $130 \mathrm{~mm}$, which presented more similar diets, suggesting that juveniles and adults do not have large differences in diet composition. Differences between the smallest size classes are probably mainly related to the amount of food eaten and in particular to the low feeding activity measured in the smallest late larvae. Anchovy ranging between 10 and $29 \mathrm{~mm}$ TL have incomplete development of the digestive tract which comprises an indistinct cylinder. The amount of ingested prey notably increased at total lengths between 30 and $39 \mathrm{~mm}$, when the formation of the stomach begins, allowing for the storage of greater quantities of food. Individuals between 40 and $60 \mathrm{~mm}$, whose tegument pigmentation and stomach were already complete, had maximal levels of stomach replenishment, particularly related to their body mass ( $F$ index in Fig. 3). The fact that anchovy of this size presented high values of both prey number and fullness index is probably due to higher metabolic needs.

\section{Feeding selection}

Within the considered size range of the present study, the dimension of particles does not seem to be a limiting factor in food selection: late larvae and juveniles were able to ingest prey whose dimensions were similar to those ingested by adults, and no relationship was found between anchovy length and the maximal size of ingested prey. The principal prey of Engraulis encrasicolus were small-sized copepods measuring about 0.2 to 0.3 or 0.5 to $0.6 \mathrm{~mm}$ in prosoma length.

Although by WP2 net sampling we obtained an incomplete planktonic spectra and could not consider plankton patchiness, some considerations about feeding selectivity are possible. The sizes of prey ingested were different from those of the most frequent mesozooplanktonic organisms in the field (Fig. 6), suggesting a discrimination of food particles by anchovy in all size classes. Ivlev's selection index (Fig. 7) confirmed that European anchovy late larvae, juveniles and adults were able to select specific food items and preferred small copepods such as Euterpina acutifrons and Oncaea spp. Even if the WP2 net may have underestimated the presence of small copepods at sea (e.g. Munk et al. 2003), the numerical dominance of these 2 small copepods observed in anchovy gut contents (Table A1) support Ivlev's selection index results. Further proof that feeding did not occur through indiscriminate filtration is that despite the extremely high concentrations of siphonophores, ophiopluteii, chaetognats, appendicularians and doliolids in the environment, these organisms were completely avoided by anchovy.

Several laboratory studies have shown that fish feeding on small particles (as small pelagic fishes) have 2 different feeding behaviours: filter-feeding, essentially non-selective, and particulate-feeding, which allows the selection of food on a dimensional basis (e.g. Gibson \& Ezzi 1985, James \& Findlay 1989, van der Lingen 1994). Feeding mode essentially depends on the dimensions and density of prey; generally, species showing this feeding plasticity, filter when high concentrations of small food particles (e.g. phytoplankton or zooplankton of small dimensions) are present and use oriented suction on larger prey. The ability to 
switch from one feeding type to the other is surely an advantage in the marine environment inhabited by clupeids, where food is patchily distributed and fish must cope with complex spatial and temporal variations in food density and dimensions. Filtering was observed in Engraulis mordax (Konchina 1991) and in E. capensis (Gibson \& Ezzi 1990) in the presence of small prey, while raptorial feeding occurred in the presence of large prey independently of food concentration. James \& Findlay (1989) reported that South African anchovy E. capensis switched from filter feeding to particulate feeding at a threshold prey size of $700 \mu \mathrm{m}$. Similarly, Bulgakova (1993) found that in E. encrasicolus, inert organisms such as phytoplankton and copepod eggs were ingested through filtering, while large and fast-swimming prey, such as adult copepods and fish larvae, were caught by biting. Recently, van der Lingen et al. (2006), in a review on E. encrasicolus and Sardinops sagax in the southern Benguela, pointed out that anchovy feed predominantly by particulate feeding, feeding inefficiently on phytoplankton and deriving the bulk of their dietary input from large zooplankton (anchovy showing higher weight-standardized clearance rates than sardine for prey $>580 \mu \mathrm{m}$ ). All these studies were carried out on adult stage fish, but our results strongly suggest that similar behaviour may also occur in juveniles.

During the sampling period, the mesozooplankton community was dominated by several copepod species of small sizes and by cladocerans (Table A2). Nevertheless, Oncaea spp. and Euterpina acutifrons were preferred by anchovy, suggesting that these species were more vulnerable to anchovy predation. The observed preference of European anchovy for a few copepod species of small sizes might be related to (1) the abundance of copepod species of small sizes in the Adriatic Sea (Kamburska \& Fonda Umani 2006), and (2) species-specific behavioural (e.g. swimming patterns, patchy distribution) and/or physical characteristics (e.g. colour, bioluminescence) of the prey.

The importance of well-defined prey items means that fish attention is focused on particular prey types. James \& Findlay (1989) showed that on a short temporal scale, anchovy seem to 'learn' to discriminate between different food targets. The authors hypothesized that Enraulis capensis acquires target-images to search. This idea came from the observation, under experimental conditions, that the reaction distance and the efficiency in catching food particles tend to increase after offering consecutively the same prey type. Anchovy probably filter planktonic organisms, but only when they encounter an adequate patch of prey; in other words, the fish filters solely when it is energetically convenient to switch from biting on single prey to indiscriminate filtering. The shape of the stomach, with the corpus of the stomach extending backwards into a caecum, whose size is highly variable, may sustain this hypothesis. Attempts have been made to interpret such variation in terms of diet, and it has been suggested, for example, that the presence of a large caecum in active predaceous swimmers, such as Scomber spp. (Suyehiro 1941), may be correlated with their capacity to attack shoals of fish and consume large quantities of prey in a short time. This explanation may also be applied to anchovy when the consistent number of ingested prey recovered in the present study is considered.

Future research should focus on extensive sampling which considers both seasonal and spatial variation of the relationship between small pelagic diet and ambient mesozooplankton composition. Small copepods seem to be a fundamental trophic link for anchovy in the Adriatic Sea. Therefore, insights into the behaviour and ecology of small copepods would be of great importance in understanding the drivers of feeding strategies of small pelagic fish species.

Acknowledgements. The present study was financially supported by the 'Fish and Fronts' Project of NOAA-Great Lakes Environmental Research Laboratory and partially by the European Project SARDONE (Improving assessment and management of small pelagic species in the Mediterranean, FP6-44294). Special thanks to P. Ganis and G. Cossarini for their support in the statistical analysis and B. Morello and M. Costantini for helpful comments on the manuscript. The authors also thank M. Cigar, S. Legovini, A. de Olazabal and S. Parlato for their contribution in taxonomic identification of prey and the members of the crew on the RV 'G. Dalla Porta' of the ISMAR (CNR) institute.

\section{LITERATURE CITED}

Angelescu V, Anganuzzi A (1981) Resultados sobre la alimentacion de la anchoita (Engraulis anchoita) en el area explotada poe el B/I 'Shinkai Maru' durantes les campanas VI (21-9-78/12-10-78) y VIII $(20-11-78 / 19-12-$ 78) en el Mar Argentino. Contrib Inst Nac Invest Pesq 383: 281-298

> Ara K (2001) Temporal variability and production of Euterpina acutifrons (Copepoda: Harpacticoida) in the Cananéia Lagoon estuarine system, So Paulo, Brazil. Hydrobiologia 453-454:177-187

Berg J (1979) Discussion of methods of investigating the food of fishes, with reference to a preliminary study of the prey of Gobiusculus flavescens (Gobiidae). Mar Biol 50: 263-273

Blaxter JHS (1986) Development of sense organs and behaviour of teleost larvae with special reference to feeding and predator avoidance. Trans Am Fish Soc 115:98-114

Bray TR, Curtis JT (1957) An ordination of the upland forest communities of southern Wisconsin. Ecol Monogr 27: 325-349

Budnichenko EV, Firulina AV, Bulgakova YV (1999) Feeding conditions of Azov Sea anchovy Engraulis encrasicolus maeoticus during summer-fall 1995-1996. J Ichthyol 39: 248-255

Bulgakova YV (1993) Diurnal dynamics of feeding in anchovy, Engraulis encrasicolus, and factors determining 
it. J Ichthyol 33:395-400

Bulgakova YV (1996) Feeding in the Black Sea anchovy: diet composition, feeding behaviour, feeding periodicity and daily rations. Sci Mar 60(Suppl 2):283-284 (Abstract)

Buljan M (1964) An estimate of productivity of the Adriatic Sea made on the basis of its hydrographic properties. Acta Adriat 11:35-45

Cataletto B, Fonda Umani S (1994) Seasonal variations in carbon and nitrogen content of Acartia clausi (Copepoda, Calanoida) in the Gulf of Trieste (Northern Adriatic Sea). Hydrobiologia 292-293:283-288

Chiappa-Carrara X, Gallardo-Cabello M (1993) Feeding behaviour and dietary composition of the Northern anchovy, Engraulis mordax Girard (Pisces: Engraulidae) off Baja California, Mexico. Cienc Mar 19:285-305

> Chisholm LA, Roff JC (1990) Size-weight relationships and biomass of tropical neritic copepods off Kingston, Jamaica. Mar Biol 106:71-77

Christensen V, Pauly D (2004) Placing fisheries in their ecosystem context, an introduction. Ecol Model 172: 103-107

Cingolani N, Kariš T, Sinovčić G, Kapedani E (2003) Anchovy (Engraulis encrasicolus, L.) stock assessment in the Adriatic Sea: 1975-2002. AdriaMed Occasional Papers 9:1-12

Clarke KR, Warwick RM (2001) Change in marine communities: an approach to statistical analysis and interpretation. Primer-E, Plymouth Marine Laboratory, Plymouth

Coll M, Santojanni A, Palomera I, Tudela S, Arneri E (2007) An ecological model of the Northern and Central Adriatic Sea: analysis of ecosystem structure and fishing impacts. J Mar Syst 67:119-154

$>$ Conway DVP, Coombs SH, Smith C (1998) Feeding of anchovy Engraulis encrasicolus larvae in the northwestern Adriatic Sea in response to changing hydrobiological conditions. Mar Ecol Prog Ser 175:35-49

Coombs SH, Giovanardi O, Halliday NC, Franceschini G and others (2003) Wind mixing, food availability and mortality of anchovy larvae Engraulis encrasicolus in the northern Adriatic Sea. Mar Ecol Prog Ser 248:221-235

Cortés E (1997) A critical review of methods of studying fish feeding based on analysis of stomach contents: application to elasmobranch fishes. Can J Fish Aquat Sci 54: 726-738

Degobbis D, Precali R, Ivančić I, Smodlaka N, Fuks D, Kveder $\mathrm{S}$ (2000) Long-term changes in the Adriatic ecosystem related to anthropogenic eutrophication. Int $\mathrm{J}$ Environ Pollut 13:495-533

Durbin EG, Durbin AG (1978) Length and weight relationships of Acartia clausi from Narragansett Bay, RI. Limnol Oceanogr 23:958-969

Ferreira PL, Ré P (1993) Feeding of larval anchovy, Engraulis encrasicolus (L.), in the Mira estuary (Portugal). Port Zool 2:483-493

Fonda Umani S (1996) Pelagic production and biomass in the Adriatic Sea. Sci Mar 60:65-77

Fonda Umani S, Specchi M, Buda-Dancevich M, Zanolla F (1979) Lo zooplancton raccolto presso le due bocche principali della Laguna di Grado (Alto Adriatico - Golfo di Trieste). I. Dati quantitativi. Boll Soc Adriat Sci 63:83-95

Fonda Umani S, Franco P, Ghirardelli E, Malej A (1992) Outline of the oceanography and the plankton of the Adriatic Sea. In: Colombo G, Ferrari I, Ceccherelli VU, Rossi R (eds) Marine eutrophication and population dynamics. Proc 25th Eur Mar Biol Symp, 10-15 Sep 1990, Ferrara, Italy. Olsen \& Olsen, Fredensborg, p 347-365

Franco P (1973) L'influenza del Po sui caratteri oceanografici e sulla distribuzione della biomassa planctonica nell'Adri- atico settentrionale. Ann Univ Ferrara 1:95-117

Fukami K, Watanabe A, Fujita S, Yamaoka K, Nishijima T (1999) Predation on naked protozoan microzooplankton by fish larvae. Mar Ecol Prog Ser 185:285-291

Gibson RN, Ezzi IA (1985) Effect of particle concentration on filter- and particulate-feeding in the herring Clupea harengus. Mar Biol 88:109-116

Gibson RN, Ezzi IA (1990) Relative importance of prey size and concentration in determining the feeding behaviour of the herring Clupea harengus. Mar Biol 107:357-362

> Hay SJ, Kiørboe T, Matthews A (1991) Zooplankton biomass and production in the North Sea during the Autumn Circulation Experiment, October 1987-March 1988. Cont Shelf Res 11:1453-1476

Hunter JR, Dorr H (1982) Thresholds for filter feeding in northern anchovy, Engraulis mordax. Calif Coop Oceanic Fish Invest Data Rep 23:198-204

> Hyslop EJ (1980) Stomach contents analysis: a review of methods and their application. J Fish Biol 17:411-429

Ivlev VS (1955) Experimental ecology of feeding fishes. Yale University Press, New Haven, CT

James AG (1987) Feeding ecology, diet and field-based studies on feeding selectivity of the Cape anchovy Engraulis capensis Gilchrist. S Afr J Mar Sci 5:673-692

James AG, Findlay KP (1989) Effect of particle size and concentration on feeding behaviour, selectivity and rates of food ingestion by Cape anchovy Engraulis capensis. Mar Ecol Prog Ser 50:275-294

Kamburska L, Fonda Umani S (2006) Long-term copepod dynamics in the Gulf of Trieste (northern Adriatic Sea): recent changes and trends. Clim Res 31:195-203

Kane J (1984) The feeding habits of co-occuring cod and haddock larvae from Georges Bank. Mar Ecol Prog Ser 16: 9-20

King DPF, Macleod PR (1976) Comparison of the food and the filtering mechanism of pilchard Sardinops ocellata and anchovy Engraulis capensis off South West Africa, 1971-1972. Invest Rep Sea Fish Res Inst Cape Town 111:1-29

> Kiørboe T, Sabatini M (1994) Reproductive and life cycle strategies in egg-carring cyclopoid and free-spawning calanoid copepods. J Plankton Res 16:1353-1366

Konchina YV (1991) Trophic status of the Peruvian anchovy and sardine. J Ichthyol 31:59-72

Koslow JA (1981) Feeding selectivity of schools of northern anchovy, Engraulis mordax, in the Southern California Bight. Fish Bull 79:131-142

La Mesa M, Tirelli V, Borme D, Di Poi E, Legovini S, Fonda Umani S (2008) Feeding ecology of the transparent goby Aphia minuta (Pisces, Gobiidae) in the northwestern Adriatic Sea. Sci Mar 72:99-108

Last JM (1978) The food of three species of gadoid larvae in the eastern English Channel and southern North Sea. Mar Biol 48:377-386

- Libralato S, Christensen V, Pauly D (2006) A method for identifying keystone species in food web models. Ecol Model 195:153-171

Mariotti A, Struglia MV, Zeng N, Lau KM (2002) The hydrological cycle in the Mediterranean region and implications for the water budget of the Mediterranean Sea. J Clim 15: 1674-1689

McLaren IA, Avendaño P (1995) Prey field and diet of larval cod on Western Bank, Scotian Shelf. Can J Fish Aquat Sci 52:448-463

McLaren IA, Avendaño P, Taggart CT, Lochmann SE (1998) Feeding by larval cod in different water masses on Western Bank, Scotian Shelf. Fish Oceanogr 6:250-265 
Mikhman AS, Tomanovich LV (1977) The feeding of the Azov anchovy, Engraulis encrasicolus maeoticus. J Ichthyol 17: $240-244$

Munk P, Hansen BW, Nielsen TG, Thomsen HA (2003) Changes in plankton and fish larvae communities across hydrographic fronts off West Greenland. J Plankton Res 25:815-830

O'Connell CP (1972) The interrelation of biting and filtering in the feeding activity of the northern anchovy (Engraulis mordax). J Fish Res Board Can 29:285-293

Ogawa Y, Nakahara T (1979) Interrelationships between pelagic fishes and plankton in the coastal fishing ground of the southwestern Japan Sea. Mar Ecol Prog Ser 1: $115-122$

Omori M (1969) Weight and chemical composition of some important oceanic zooplankton in the North Pacific Ocean. Mar Biol 3:4-10

Palomera I, Olivar MP, Salat J, Sabatés A, Coll M, García A, Morales-Nin B (2007) Small pelagic fish in the NW Mediterranean Sea: an ecological review. Prog Oceanogr 74:377-396

Piccinetti C (2001) Distribution of anchovy (Engraulis encrasicolus) eggs in the Adriatic Sea. Priority topics related to small pelagic fishery resources of the Adriatic Sea. AdriaMed Tech Doc 3:78-81

Pinkas L, Oliphant M, Iverson ILK (1971) Food habits of albacore, bluefin tuna and bonito in California waters. Calif Fish Game 152:1-105

Plounevez S, Champalbert G (1999) Feeding behaviour and trophic environment of Engraulis encrasicolus (L.) in the Bay of Biscay. Estuar Coast Shelf Sci 49:177-191

> Plounevez S, Champalbert G (2000) Diet, feeding behaviour and trophic activity of Engraulis encrasicolus (L.) in the Gulf of Lions (Mediterranean Sea). Oceanol Acta 23: 175-192

Poulain PM, Kourafalou VH, Cushman-Roisin B (2001) Northern Adriatic Sea. In: Cushman-Roisin B, Gaãiç M, Poulain PM, Artegiani A (eds) Physical oceanography of the Adriatic Sea. Kluwer Academic Publishers, Dordrecht, p 143-165

Razouls S (1981) Etude écophysiologique de deux copépodes pélagiques. Essai d'application au mesozooplancton des principes rélatifs aux systhèmes. PhD thesis, Université Pierre et Marie Curie, Paris VI

Regner S (1971) Prilog poznavanju ishrane postlarava brgljuna, Engraulis encrasicolus (Linnaeus, 1758), u srednjem Jadranu. Ekologija 6:157-164

Robert D, Castonguay M, Fortier L (2008) Effects of intra- and inter-annual variability in prey field on the feeding selecivity of larval Atlantic mackerel (Scomber scombrus). J Plankton Res 30:673-688

Rossi S, Sabatés A, Latasa M, Reyes E (2006) Lipid biomarkers and trophic linkages between phytoplankton, zooplankton and anchovy (Engraulis encrasicolus) larvae in the NW Mediterranean. J Plankton Res 28:551-562

Sabatini M, Kiørboe T (1994) Egg production, growth and development of the cyclopoid copepod Oithona similis. J Plankton Res 16:1329-1351

Sautour B, Castel J (1995) Spring zooplankton distribution and production of the copepod Euterpina acutifrons in Marennes-Oléron Bay (France). Hydrobiologia 310: 163-175

Sciolis D (2000) Comunità planctonica e contenuti stomacali della specie planctonofaga Engraulis encrasicolus L. (acciuga) durante il suo periodo riproduttivo nel Golfo di Trieste. MS thesis, Università degli Studi di Trieste
Sinovčić G (1999) Some ecological aspects of juvenile anchovy, Engraulis encrasicolus (L.), under the estuarine conditions (Novigrad Sea - Central Eastern Adriatic). Acta Adriat 40(Suppl):99-107

Specchi M, Orlandi C, Radin B, Manetti MF, Cassetti P (1999) Observations on the occurrence of Penilia avirostris Dana and the eggs of Engraulis encrasicolus L. in the Gulf of Trieste (Northern Adriatic Sea). Boll Soc Adriat Sci 78: 309-316

Stamatopoulos C (1993) Trends in catches and landings, Mediterranean and Black Sea fisheries: 1972-1991. FAO Fish Circ 855:1-177

Štirn J (1969) The north Adriatic pelagial, its oceanological characteristics, structure and distribution of the biomass during the year 1965. Diss Acad Sci Art Slov 12:1-92 (in Slovenian with English Abstract)

Suyehiro Y (1941) A study on the digestive system and feeding habits of fish. Jpn J Zool 10:1-303

Tanaka H, Aoki I, Ohshimo S (2006) Feeding habits and gill raker morphology of three planktivorous pelagic fish species off the coast of northern and western Kyushu in summer. J Fish Biol 68:1041-1061

Theilacker G (1980) Changes in body measurements of larval northern anchovy Engraulis mordax and other fishes due to handling and preservation. Fish Bull 78:685-692

Totti C, Civitarese G, Acri F, Barletta D, Candelari G, Paschini E, Solazzi A (2000) Seasonal variability of phytoplankton populations in the middle Adriatic sub-basin. J Plankton Res 22:1735-1756

Tudela S, Palomera I (1995) Diel feeding intensity and daily ration in the anchovy Engraulis encrasicolus in the northwest Mediterranean Sea during the spawning period. Mar Ecol Prog Ser 129:55-61

Tudela S, Palomera I (1997) Trophic ecology of the European anchovy Engraulis encrasicolus in the Catalan Sea (northwest Mediterranean). Mar Ecol Prog Ser 160:121-134

- Tudela S, Palomera I, Quilez G (2002) Feeding of anchovy Engraulis encrasicolus larvae in the north-west Mediterranean. J Mar Biol Assoc UK 82:349-350

Uye S, Aoto I, Onbé T (2002) Seasonal population dynamics and production of Microsetella norvegica, a widely distributed but little-studied marine planktonic harpacticoid copepod. J Plankton Res 24:143-153

van der Lingen CD (1994) Effect of particle size and concentration on the feeding behaviour of adult pilchard Sardinops sagax. Mar Ecol Prog Ser 109:1-13

van der Lingen CD (2002) Diet of sardine Sardinops sagax in the southern Benguela upwelling ecosystem. S Afr J Mar Sci 24:301-316

van der Lingen CD, Hutchings L, Field JG (2006) Comparative trophodynamics of anchovy Engraulis encrasicolus and sardine Sardinops sagax in the southern Benguela: Are species alternations between small pelagic fish trophodynamically mediated? Afr J Mar Sci 28:465-477

van der Lingen $C D$, Bertrand $A$, Bode $A$, Brodeur R and others (2009) Trophic dynamics. In: Checkley D, Alheit J, Oozeki Y, Roy C (eds) Climate change and small pelagic fish. Cambridge Univeristy Press, Cambridge, p 112-157

Whitehead PJP, Nelson GJ, Wongratana T (1988) FAO species catalogue. Vol. 7. Clupeoid fishes of the world (Suborder Clupeoidei). An annotated and illustrated catalogue of the herrings, sardines, pilchards, sprats, shads, anchovies and wolf-herrings. Part 2 - Engraulidae. FAO Fish Synop 125: 305-579 
Appendix 1. Dietary indexes (Table A1) and zooplankton species composition in the environment (Table A2)

Table A1. Dietary indexes obtained at night and during the day. Total stomach contents by number (N), frequency of occurrence (O), weight (DW) and index of relative importance (IRI) calculated for prey items in anchovy size classes. Late larvae: 30 to $39 \mathrm{~mm}$; juveniles: 40 to $89 \mathrm{~mm}$; adults: $\geq 90 \mathrm{~mm}$ total length (TL). $\mathrm{n}$ : number of anchovy analysed; indet.: indeterminate

\begin{tabular}{|c|c|c|c|c|c|c|c|c|c|c|c|c|}
\hline & \multirow{2}{*}{$\mathrm{O}(\%)$} & \multicolumn{2}{|c|}{ - TL 30-39 mm } & \multirow[b]{2}{*}{ IRI (\%) } & \multirow{2}{*}{$\overline{O(\%)}$} & \multicolumn{2}{|c|}{ TL $40-89 \mathrm{~mm}$} & \multirow[b]{2}{*}{ IRI (\%) } & \multirow[b]{2}{*}{$\mathrm{O}(\%)$} & \multicolumn{2}{|c|}{$-\mathrm{TL}>90 \mathrm{~mm}-$} & \multirow[b]{2}{*}{ IRI $(\%$} \\
\hline & & $\mathrm{N}(\%)$ & $\mathrm{W}(\%)$ & & & $\mathrm{N}(\%)$ & $\mathrm{W}(\%)$ & & & $\mathrm{N}(\%)$ & $\mathrm{W}(\%)$ & \\
\hline \multicolumn{13}{|l|}{ NIGHT } \\
\hline \multicolumn{13}{|l|}{$\begin{array}{l}\text { Gastropoda } \\
\text { Gastropoda pediveliger }\end{array}$} \\
\hline Gastropoda pedivelige & & & & & 6.43 & 0.17 & 0.12 & 0.01 & 3.70 & 0.06 & 0.03 & $<0.01$ \\
\hline \multicolumn{13}{|l|}{ Bivalvia } \\
\hline $\begin{array}{l}\text { Bivalvia veliger } \\
\text { Polychaeta }\end{array}$ & 77.78 & 25.10 & 48.94 & 43.34 & 91.81 & 26.18 & 38.19 & 40.22 & 79.63 & 17.60 & 20.88 & 24.86 \\
\hline $\begin{array}{l}\text { Polychaeta larva } \\
\text { Cladocera }\end{array}$ & 11.11 & 0.40 & 1.19 & 0.13 & 10.53 & 0.11 & 0.24 & 0.03 & 3.70 & 0.08 & 0.15 & 0.01 \\
\hline Evadne spp. & 77.78 & 4.86 & 3.35 & 4.81 & 40.35 & 1.97 & 0.93 & 0.80 & 62.96 & 5.40 & 2.18 & 3.87 \\
\hline Penilia avirostris & 55.56 & 6.07 & 3.78 & 4.12 & 56.73 & 3.50 & 1.63 & 1.98 & 57.41 & 7.67 & 2.90 & 4.92 \\
\hline Podon spp. & 11.11 & 0.40 & 0.34 & 0.06 & 11.11 & 0.21 & 0.13 & 0.03 & 29.63 & 1.33 & 0.67 & 0.48 \\
\hline & \multicolumn{11}{|c|}{ Ostracoda } & 0.11 \\
\hline $\begin{array}{l}\text { Ostracoda juveniles } \\
\text { Copepoda }\end{array}$ & 11.11 & 0.40 & 1.27 & 0.14 & 58.48 & 3.41 & 7.98 & 4.53 & 35.19 & 2.19 & 4.16 & 1.81 \\
\hline Copepoda nauplius & 55.56 & 2.43 & 0.09 & 1.05 & 33.92 & 1.77 & 0.05 & 0.42 & 9.26 & 1.47 & 0.03 & 0.11 \\
\hline \multicolumn{13}{|c|}{ Calanoida } \\
\hline Temora stylifera & 33.33 & 1.62 & 5.12 & 1.69 & 38.60 & 0.83 & 5.01 & 1.53 & 55.56 & 2.52 & 11.28 & 6.22 \\
\hline $\begin{array}{l}\text { Clauso-Paracalanidae } \\
\text { Cyclopoida }\end{array}$ & 11.11 & 0.40 & 3.79 & 0.35 & 43.27 & 1.22 & 2.56 & 1.11 & 42.59 & 2.13 & 4.45 & 2.27 \\
\hline \multicolumn{12}{|l|}{ Poecilostomatoida } & 0.38 \\
\hline Corycaeus spp. & & & & & 19.88 & 0.36 & 0.28 & 0.09 & 20.37 & 0.50 & 0.34 & 0.14 \\
\hline \multicolumn{13}{|l|}{ Harpacticoida } \\
\hline Clytemnestra rostrata & & & & & 1.17 & 0.01 & 0.02 & $<0.01$ & 1.85 & 0.03 & 0.04 & $<0.01$ \\
\hline Euterpina acutifrons & 88.89 & 22.27 & 10.50 & 21.92 & 91.23 & 26.56 & 9.34 & 22.29 & 87.04 & 20.70 & 6.45 & 19.17 \\
\hline Microsetella rosea & 33.33 & 1.21 & 0.39 & 0.40 & 39.18 & 1.22 & 0.37 & 0.43 & 24.07 & 0.61 & 0.17 & 0.15 \\
\hline $\begin{array}{l}\text { Harpacticoida indet. } \\
\text { Cirripedia }\end{array}$ & & & & & 5.85 & 0.06 & 0.03 & $<0.01$ & 1.85 & 0.03 & 0.01 & $<0.01$ \\
\hline Cirripedia nauplius & 22.22 & 0.81 & 0.70 & 0.25 & 9.94 & 0.13 & 0.08 & 0.01 & 9.26 & 0.14 & 0.07 & 0.02 \\
\hline Cirripedia cypris & & & & & 0.58 & 0.01 & $<0.01$ & $<0.01$ & & & & \\
\hline \multicolumn{13}{|l|}{ Decapoda } \\
\hline Macrura larva & & & & & 0.58 & 0.02 & 9.04 & 0.04 & & & & \\
\hline Decapoda nauplius & & & & & 0.58 & 0.01 & $<0.01$ & $<0.01$ & 1.85 & 0.03 & 0.01 & $<0.01$ \\
\hline Decapoda zoea+mysis & & & & & 6.43 & 0.07 & 0.80 & 0.04 & 5.56 & 0.08 & 0.73 & 0.04 \\
\hline \multicolumn{13}{|l|}{ Isopoda } \\
\hline Isopoda indet. & & & & & 1.17 & 0.02 & 0.06 & $<0.01$ & 11.11 & 0.25 & 0.37 & 0.06 \\
\hline Amphipoda & & & & & & & & & & & & \\
\hline $\begin{array}{l}\text { Amphipoda indet. } \\
\text { Bacillariphyceae }\end{array}$ & & & & & 1.75 & 0.02 & 8.49 & 0.10 & 3.70 & 0.08 & 30.95 & 0.93 \\
\hline Coscinodiscus spp. & & & & & 4.09 & 0.04 & & $<0.01$ & 3.70 & 0.08 & 30.95 & 0.93 \\
\hline Dinoflagellida & & & & & & & & & & & & \\
\hline Ceratium spp. & & & & & & & & & 7.41 & 0.83 & & 0.05 \\
\hline Dynophysis caudata & & & & & 1.17 & 0.01 & & & & & & \\
\hline Phaeocystis spp. & & & & & 2.92 & 0.04 & & & & & & \\
\hline $\begin{array}{l}\text { Protoperidinium } \\
\text { claudicans }\end{array}$ & 11.11 & 0.40 & & 0.03 & 2.34 & 0.02 & & & & & & \\
\hline $\begin{array}{l}\text { Protoperidinium } \\
\text { conicum }\end{array}$ & & & & & 4.68 & 0.06 & & $<0.01$ & 1.85 & 0.03 & & $<0.01$ \\
\hline $\begin{array}{l}\text { Protoperidinium } \\
\text { depressum }\end{array}$ & 33.33 & 3.24 & & 0.81 & 34.50 & 1.31 & & 0.31 & 12.96 & 1.16 & & 0.12 \\
\hline $\begin{array}{l}\text { Protoperidinium } \\
\text { divergens }\end{array}$ & & & & & 2.34 & 0.04 & & $<0.01$ & & & & \\
\hline $\begin{array}{l}\text { Protoperidinium } \\
\text { mediterraneum }\end{array}$ & & & & & 0.58 & 0.01 & & $<0.01$ & & & & \\
\hline $\begin{array}{l}\text { Protoperidinium } \\
\text { oblonqum }\end{array}$ & & & & & 0.58 & 0.01 & & $<0.01$ & 1.85 & 0.03 & & $<0.01$ \\
\hline $\begin{array}{l}\text { Protoperidinium } \\
\text { steinii }\end{array}$ & & & & & 1.75 & 0.02 & & $<0.01$ & & & & \\
\hline
\end{tabular}


Table A1 (continued)

\begin{tabular}{|c|c|c|c|c|c|c|c|c|c|c|c|c|}
\hline & \multicolumn{3}{|c|}{- TL $30-39 \mathrm{~mm}$} & \multirow[b]{2}{*}{ IRI (\%) } & \multicolumn{3}{|c|}{$\longrightarrow$ TL $40-89 \mathrm{~mm}$} & \multirow{2}{*}{$\overline{\text { IRI (\%) }}$} & \multirow[b]{2}{*}{$\mathrm{O}(\%)$} & \multicolumn{2}{|c|}{$-\mathrm{TL}>90 \mathrm{~mm}$} & \multirow[b]{2}{*}{ IRI $(\%$} \\
\hline & $\mathrm{O}(\%)$ & $\mathrm{N}(\%)$ & $\mathrm{W}(\%)$ & & $\mathrm{O}(\%)$ & $\mathrm{N}(\%)$ & $\mathrm{W}(\%)$ & & & $\mathrm{N}(\%)$ & $\mathrm{W}(\%)$ & \\
\hline \multicolumn{13}{|l|}{ Tintinnida } \\
\hline Stenosemella ventricos & & & & & & & & & 1.85 & 0.17 & & $<0.01$ \\
\hline \multicolumn{13}{|l|}{ Other } \\
\hline Invertebrate eggs & & & & & 9.36 & 0.51 & 0.52 & 0.07 & 1.85 & 0.08 & 0.06 & $<0.01$ \\
\hline $\mathbf{n}$ & 9 & 58 & 58 & 58 & 171 & 180 & 180 & 180 & 54 & 59 & 59 & 59 \\
\hline \multicolumn{13}{|l|}{ DAY } \\
\hline & \multicolumn{11}{|c|}{ Bivalvia } & 0.06 \\
\hline $\begin{array}{l}\text { Bivalvia veliger } \\
\text { Polychaeta }\end{array}$ & 17.39 & 1.36 & 3.71 & 0.70 & 61.00 & 1.53 & 4.45 & 2.08 & 96.30 & 4.00 & 1.50 & 4.51 \\
\hline $\begin{array}{l}\text { Polychaeta larva } \\
\text { Cladocera }\end{array}$ & \multicolumn{11}{|c|}{ Cladocera } & $<0.01$ \\
\hline Evadne spp. & 2.17 & 0.04 & 0.04 & $<0.01$ & 10.00 & 0.04 & 0.04 & $<0.01$ & 66.67 & 1.05 & 0.13 & 0.67 \\
\hline Penilia avirostris & 6.52 & 0.44 & 0.38 & 0.04 & 2.00 & 0.02 & 0.02 & $<0.01$ & 70.37 & 1.04 & 0.12 & 0.70 \\
\hline Podon spp. & & & & & 7.00 & 0.01 & 0.01 & $<0.01$ & 44.44 & 0.23 & 0.04 & 0.10 \\
\hline $\begin{array}{l}\text { Evadne eggs } \\
\text { Ostracoda }\end{array}$ & 4.35 & 0.24 & 0.07 & 0.01 & 14.00 & 0.06 & 0.02 & $<0.01$ & 44.44 & 0.29 & 0.01 & 0.11 \\
\hline $\begin{array}{l}\text { Ostracoda juveniles } \\
\text { Copepoda }\end{array}$ & 4.35 & 0.08 & 0.35 & 0.01 & 36.00 & 0.23 & 1.07 & 0.27 & 74.07 & 0.16 & 0.10 & 0.16 \\
\hline Copepoda nauplius & 8.70 & 0.44 & 0.04 & 0.03 & 18.00 & 0.06 & $<0.01$ & 0.01 & 22.22 & 0.06 & $<0.01$ & 0.01 \\
\hline \multicolumn{13}{|c|}{ Calanoida } \\
\hline Acartia clausi & & & & & 1.00 & $<0.01$ & 0.01 & $<0.01$ & 7.41 & 0.01 & $<0.01$ & $<0.01$ \\
\hline Calanus helgolandicus & & & & & 1.00 & $<0.01$ & 0.10 & $<0.01$ & 3.70 & $<0.01$ & 0.04 & $<0.01$ \\
\hline Centropages kroyeri & 2.17 & 0.04 & 0.41 & 0.01 & & & & & & & & \\
\hline Centropages typicus & & & & & 4.00 & 0.01 & 0.08 & $<0.01$ & & & & \\
\hline $\begin{array}{l}\text { Nannocalanus minor } \\
\text { Temora stylifera }\end{array}$ & 2174 & 100 & 1258 & 233 & 4900 & 0.46 & 6.87 & 204 & $\begin{array}{r}7.41 \\
8519\end{array}$ & 0.01 & 0.01 & $<0.01$ \\
\hline \multicolumn{12}{|c|}{ Cyclopoida } & 1.84 \\
\hline \multicolumn{12}{|l|}{ Poecilostomatoida } & 0.32 \\
\hline Copilia quadrata & & & & & & & & & 11.11 & 0.01 & 0.02 & $<0.01$ \\
\hline Corycaeus speciosus & & & & & & & & & 3.70 & 0.01 & $<0.01$ & $<0.01$ \\
\hline Corycaeus spp. & 10.87 & 0.20 & 0.43 & 0.05 & 34.00 & 0.09 & 0.15 & 0.05 & 81.48 & 0.54 & 0.12 & 0.46 \\
\hline $\begin{array}{l}\text { Oncaea spp. } \\
\text { Harpacticoida }\end{array}$ & 52.17 & 17.90 & 17.46 & 14.56 & 94.00 & 41.64 & 43.24 & 45.45 & 96.30 & 39.96 & 5.34 & 37.16 \\
\hline \multicolumn{5}{|c|}{ Clytemnestra rostrata } & 3.00 & 0.01 & 0.02 & $<0.01$ & 11.11 & 0.02 & 0.01 & $<0.01$ \\
\hline Euterpina acutifrons & 80.43 & 73.50 & 50.15 & 78.51 & 95.00 & 53.63 & 35.54 & 48.26 & 96.30 & 48.73 & 4.79 & 43.92 \\
\hline Microsetella rosea & 8.70 & 0.24 & 0.12 & 0.02 & 70.00 & 0.91 & 0.57 & 0.59 & 88.89 & 0.87 & 0.08 & 0.72 \\
\hline $\begin{array}{l}\text { Harpacticoida indet. } \\
\text { Cirripedia }\end{array}$ & 10.87 & 0.20 & 0.19 & 0.03 & 13.00 & 0.04 & 0.03 & $<0.01$ & 25.93 & 0.05 & 0.01 & 0.01 \\
\hline Cirripedia nauplius & & & & & & & & & 7.41 & 0.02 & $<0.01$ & $<0.01$ \\
\hline Cirripedia cypris & & & & & & & & & 3.70 & $<0.01$ & $<0.01$ & $<0.01$ \\
\hline \multicolumn{13}{|l|}{ Decapoda } \\
\hline Macrura larva & & & & & 1.00 & $<0.01$ & 0.10 & $<0.01$ & 7.41 & 0.01 & 0.39 & 0.03 \\
\hline Decapoda nauplius & & & & & 1.00 & $<0.01$ & $<0.01$ & $<0.01$ & 3.70 & $<0.01$ & $<0.01$ & $<0.01$ \\
\hline $\begin{array}{l}\text { Decapoda zoea+mysis } \\
\text { Amphipoda }\end{array}$ & 8.70 & 0.20 & 4.03 & 0.29 & 8.00 & 0.02 & 0.36 & 0.02 & 22.22 & 0.05 & 0.13 & 0.03 \\
\hline $\begin{array}{l}\text { Amphipoda indet. } \\
\text { Echinodermata }\end{array}$ & & & & & 2.00 & $<0.01$ & 2.57 & 0.03 & & & & \\
\hline $\begin{array}{l}\text { Ophiuroidea juveniles } \\
\text { Chaetognatha }\end{array}$ & & & & & 1.00 & $<0.01$ & & & & & & \\
\hline $\begin{array}{l}\text { Sagitta spp. } \\
\text { Teleostea }\end{array}$ & & & & & 1.00 & $<0.01$ & 1.56 & 0.01 & & & & \\
\hline $\begin{array}{l}\text { Engraulis encrasicolus } \\
\text { Bacillariphyceae }\end{array}$ & larva & & & & & & & & 11.11 & 0.03 & 85.02 & 8.05 \\
\hline $\begin{array}{l}\text { Coscinodiscus spp. } \\
\text { Dinoflagellida }\end{array}$ & 8.70 & 0.28 & & 0.02 & 20.00 & 0.24 & & 0.03 & 33.33 & 0.24 & & 0.07 \\
\hline Phaeocystis spp. & & & & & & & & & 3.70 & & & \\
\hline $\begin{array}{l}\text { Protoperidinium depres } \\
\text { Other }\end{array}$ & essum & & & & 2.00 & $<0.01$ & & $<0.01$ & 3.70 & 0.02 & & $<0.01$ \\
\hline Invertebrate eggs & & & & & 2.00 & 0.01 & 0.01 & $<0.01$ & 7.41 & 0.02 & $<0.01$ & $<0.01$ \\
\hline Pollen grains & & & & & 1.00 & $<0.01$ & & & & & & \\
\hline $\mathbf{n}$ & 46 & 74 & 74 & 74 & 100 & 105 & 105 & 105 & 27 & 27 & 27 & 27 \\
\hline
\end{tabular}


Table A2. Zooplankton species composition (ind. $\mathrm{m}^{-3}$ ) from horizontal plankton-net tows

\begin{tabular}{|c|c|c|c|c|c|c|c|c|c|}
\hline Taxa & 1 & 2 & 3 & 4 & $\begin{array}{c}\text { Tow } \\
5\end{array}$ & 7 & 9 & 10 & 11 \\
\hline \multicolumn{10}{|l|}{ Foraminiferida } \\
\hline $\begin{array}{l}\text { Globigerina bulloides } \\
\text { Hydrozoa }\end{array}$ & 0 & 3 & 0 & 0 & 0 & 0 & 0 & 0 & 0 \\
\hline Obelia spp. & 0 & 0 & 0 & 0 & 13 & 0 & 0 & 0 & 0 \\
\hline Siphonophora indet. & 4350 & 267 & 2928 & 72 & 162 & 1183 & 1659 & 64 & 141 \\
\hline $\begin{array}{l}\text { Hydrozoa indet. } \\
\text { Gastropoda }\end{array}$ & 669 & 5 & 251 & 2 & 13 & 370 & 261 & 4 & 42 \\
\hline Creseis acicula & 0 & 0 & 42 & 0 & 0 & 24 & 0 & 0 & 0 \\
\hline $\begin{array}{l}\text { Gastropoda pediveligera } \\
\text { Bivalvia }\end{array}$ & 223 & 33 & 753 & 15 & 30 & 299 & 41 & 30 & 203 \\
\hline $\begin{array}{l}\text { Bivalvia veligera } \\
\text { Polychaeta }\end{array}$ & 3681 & 41 & 1213 & 79 & 50 & 8438 & 343 & 37 & 131 \\
\hline $\begin{array}{l}\text { Polychaeta larvae } \\
\text { Nemertea }\end{array}$ & 112 & 30 & 460 & 11 & 84 & 968 & 137 & 30 & 91 \\
\hline $\begin{array}{l}\text { Nemertea pilidia } \\
\text { Cladocera }\end{array}$ & 0 & 8 & 0 & 0 & 0 & 0 & 14 & 0 & 3 \\
\hline Evadne nordmanni & 12270 & 360 & 14097 & 79 & 19 & 4410 & 576 & 12 & 7 \\
\hline Evadne spinifera & 0 & 147 & 0 & 0 & 2 & 12 & 329 & 0 & 0 \\
\hline Evadne tergestina & 669 & 3 & 1213 & 2 & 0 & 382 & 946 & 0 & 0 \\
\hline Penilia avirostris & 15951 & 989 & 10792 & $2 \overline{6}$ & 37 & 8211 & 3004 & 5 & 3 \\
\hline Podon intermedius & 446 & 25 & 0 & 2 & 4 & 72 & 14 & 1 & 0 \\
\hline $\begin{array}{l}\text { Podon polyphemoides } \\
\text { Ostracoda }\end{array}$ & 2789 & 41 & 3012 & 2 & 6 & 418 & 1015 & 7 & 20 \\
\hline $\begin{array}{l}\text { Ostracoda indet. } \\
\text { Copepoda }\end{array}$ & 0 & 0 & 84 & 4 & 0 & 131 & 14 & 0 & 3 \\
\hline Acartia clausi & 112 & 25 & 84 & 13 & 47 & 24 & 411 & 0 & 16 \\
\hline Calanus helgolandicus & 0 & 3 & 167 & 0 & 2 & 0 & 234 & 0 & 3 \\
\hline Calocalanus pavo & 112 & 8 & 42 & 2 & 26 & 0 & 0 & 21 & 42 \\
\hline Centropages typicus & 223 & 3 & 0 & 0 & 4 & 24 & 14 & 0 & 3 \\
\hline Centropages kroyeri & 0 & 3 & 0 & 0 & 0 & 0 & 0 & 0 & 0 \\
\hline Diaixis pygmoea & 223 & 0 & 0 & 0 & 0 & 0 & 14 & 0 & 0 \\
\hline Eucalanus elongatus & 0 & 71 & 0 & 11 & 11 & 0 & 0 & 0 & 13 \\
\hline Mecynocera clausi & 223 & 3 & 0 & 15 & 17 & 0 & 0 & 2 & 16 \\
\hline Nannocalanus minor & 112 & 0 & 84 & 26 & 37 & 0 & 0 & 1 & 10 \\
\hline Temora stylifera & 4685 & 104 & 335 & 42 & 41 & 765 & 617 & 90 & 3 \\
\hline Clauso-Paracalanidae & 5800 & 300 & 2844 & 193 & 316 & 1745 & 2332 & 192 & 882 \\
\hline $\begin{array}{l}\text { Calanoida copepodita } \\
\text { Cyclopoida }\end{array}$ & 446 & 128 & 335 & 180 & 35 & 0 & 69 & 99 & 258 \\
\hline Oithona cf. nana & 4685 & 22 & 669 & 61 & 78 & 430 & 261 & 49 & 422 \\
\hline $\begin{array}{l}\text { Oithona cf. plumifera } \\
\text { Poecilostomatoida }\end{array}$ & 1785 & 33 & 1506 & 114 & 179 & 430 & 261 & 65 & 732 \\
\hline Copilia quadrata & 0 & 0 & 0 & 2 & 0 & 0 & 14 & 1 & 3 \\
\hline Corycaeus spp. & 446 & 63 & 753 & 9 & 32 & 227 & 357 & 21 & 10 \\
\hline Oncaea spp. & 15951 & 104 & 1631 & 116 & 54 & 992 & 1029 & 100 & 82 \\
\hline $\begin{array}{l}\text { Sapphirina spp. } \\
\text { Harpacticoida }\end{array}$ & 0 & 0 & 0 & 4 & 0 & 0 & 0 & 0 & 0 \\
\hline Clytemnestra rostrata & 0 & 0 & 0 & 0 & 2 & 0 & 0 & 0 & 7 \\
\hline Euterpina acutifrons & 5466 & 25 & 2886 & 7 & 32 & 765 & 2016 & 32 & 20 \\
\hline Microsetella rosea & 0 & 0 & 0 & 0 & 4 & 0 & 0 & 1 & 0 \\
\hline $\begin{array}{l}\text { Harpacticoida indet. } \\
\text { Cirripedia }\end{array}$ & 112 & 0 & 0 & 2 & 0 & 0 & 0 & 0 & 3 \\
\hline $\begin{array}{l}\text { Cirripedia nauplii } \\
\text { Decapoda }\end{array}$ & 0 & 0 & 0 & 0 & 4 & 0 & 0 & 15 & 10 \\
\hline $\begin{array}{l}\text { Decapoda larvae } \\
\text { Phoronida }\end{array}$ & 0 & 22 & 84 & 13 & 24 & 72 & 14 & 5 & 7 \\
\hline $\begin{array}{l}\text { Phoronoidea actinotrocha } \\
\text { Echinodermata }\end{array}$ & 0 & 3 & 0 & 0 & 0 & 12 & 14 & 0 & 0 \\
\hline Ophiuroidea pluteii & 54658 & 629 & 11838 & 485 & 657 & 6143 & 9203 & 510 & 732 \\
\hline $\begin{array}{l}\text { Stelleroidea bipinnariae } \\
\text { Chaetognatha }\end{array}$ & 112 & 0 & 0 & 31 & 37 & 24 & 14 & 36 & 0 \\
\hline $\begin{array}{l}\text { Sagitta spp. } \\
\text { Urochordata }\end{array}$ & 1673 & 150 & 376 & 198 & 172 & 1028 & 1262 & 114 & 173 \\
\hline $\begin{array}{l}\text { Appendicularia indet. } \\
\text { Thaliacea }\end{array}$ & 4462 & 139 & 962 & 329 & 345 & 598 & 590 & 248 & 422 \\
\hline Doliolum spp. & 12270 & 1033 & 4559 & 51 & 63 & 1506 & 1070 & 74 & 422 \\
\hline Thalia spp. & 0 & 14 & 0 & 2 & 15 & 0 & 0 & 4 & 0 \\
\hline Urochordata larvae & 0 & 0 & 2 & 2 & 0 & 0 & 0 & 0 & 0 \\
\hline Osteichthyes & & & & & & & & & \\
\hline Teleostea eggs & 0 & 0 & 125 & 0 & 0 & 72 & 0 & 0 & 0 \\
\hline Teleostea larvae & 112 & 3 & 0 & 0 & 7 & 0 & 0 & 0 & 7 \\
\hline
\end{tabular}

